\title{
Setting the Social Agenda: Deciding to Review High-Profile Cases at the Supreme Court
}

\author{
Margaret Meriwether Cordray \\ Richard Cordray ${ }^{* *}$
}

\section{INTRODUCTION}

Every year, the United States Supreme Court decides a small handful of high-profile cases that tend to define the Court's Term, and also disproportionately shape its perceived role in American life. These cases, which may present critical struggles over the distribution of political power, as well as socially divisive issues such as religious freedom, free speech, property rights, abortion, and civil rights, not only determine how the public views the Court, but can also frame the broader cultural debate by pushing these issues to the forefront of political discourse.

The Court's decisions on whether and when to review these more politically charged cases thus have significant ramifications for the Court and for the country's social agenda. When the Court decides to hear a case involving gay rights, for example, the Court immediately raises the salience of that issue, and potentially places it in the center of the political debate. Quite apart from the Court's eventual resolution of that particular case on its merits, the very determination to hear oral argument and decide the case stands as an influential landmark in its own right.

In this Article, we consider whether the Justices act differently in deciding to grant these high-profile cases than they do in more ordinary cases. In reviewing petitions for certiorari, the Justices undoubtedly recognize that certain types of cases present more ideologically charged

Professor of Law, Capital University Law School. B.A. 1983, University of the Pacific; J.D. 1986, Boalt Hall School of Law; B.C.L. 1988, Oxford University. We thank Steve Kautz and David Stras for reading and commenting on earlier drafts, and Banks Miller for his advice and assistance on the statistical analysis. We also thank Carrie Lymanstall, Janine Maney, Lindsey McCarron, and Jarrod Shirk for their invaluable help with the research, and Minerva Sneed for her careful assistance with the data. Capital University Law School supported the preparation of this Article with a generous research stipend.

** Ohio Attorney General. B.A. 1981, Michigan State University; M.A., 1983, Oxford University; J.D. 1986, University of Chicago Law School. Mr. Cordray served as a law clerk to Justices Byron R. White and Anthony M. Kennedy, and as Ohio's Solicitor General. 
and politically important issues. In choosing to pass over or take up candidates from this subset of cases, the question is whether the Justices exhibit the same kind of behavior that they do in their standard case selection processes, or whether their decisional calculus at the certiorari stage is fundamentally different, and more strategic.

Answering this question is not easy because case selection decisions are shrouded in secrecy, and they are dependent on a wide array of considerations for each individual Justice. ${ }^{1}$ Given the inherent complexity of each Justice's own decisionmaking formula, it is difficult to gauge the full extent to which the politically or socially divisive nature of a case may influence him or her. Nonetheless, the Justices' voting records on certiorari, which can be found in the papers of retired Justices, provide a window into how the Justices individually, and the Court as a whole, behave in approaching these landmark cases.

In this Article, we use information on the Justices' certiorari votes that we gathered from the private papers of Justices Blackmun, Brennan, and Marshall to compare the Justices' voting patterns on certiorari in the high-profile cases to their voting patterns in low-profile cases over the 1983 through 1993 Terms. $^{2}$ Our study reveals strong evidence that the Justices behave even more strategically in voting to grant high-profile cases than they do generally. However, the data also suggests that the Justices are voting to grant at least some high-profile cases not because they believe they can win them, but for other reasons, such as their sense of the Court's institutional responsibility to address such cases.

\section{The Supreme COURT’s CASE SELECTION PROCESS}

\section{A. The Significance of the Decision to Decide}

As the Supreme Court decides which cases it will hear, it sets "the direction of constitutional law." " Indeed, not only deciding to decide a case, but also "[d]eciding not to decide is . . . among the most important things done by the Supreme Court." The Court's power to choose its

1. See generally Margaret Meriwether Cordray \& Richard Cordray, The Philosophy of Certiorari: Jurisprudential Considerations in Supreme Court Case Selection, 82 WASH. U. L.Q. 389, 397-451 (2004) [hereinafter Cordray \& Cordray, Philosophy of Certiorari] (discussing the secrecy of the certiorari process and the factors that influence decisionmaking at the certiorari stage).

2. Raw data on file with authors.

3. Barry Friedman, The Politics of Judicial Review, 84 TEX. L. Rev. 257, 294 (2005) ("[A]genda setting accounts for the direction of constitutional law, just as the opinions themselves account for its substance.").

4. Thurgood Marshall, Remarks at the Second Circuit Judicial Conference (September 8, 
cases allows it to shape the contours of its own agenda, and often to set the agenda for the country's political and cultural debate as well. ${ }^{5}$ Particularly with respect to cases presenting socially divisive issues, the Court's very decision to grant review "increase[s] the political salience of the issues decided-regardless of which way the Court decides the issues."

Moreover, the Justices' decisions about whether and when to take up hot button issues affect the institutional and moral authority of the Court itself. $^{7}$ While the general public has very little sense of the overall composition of the Court's docket or the details of its rulings, the Court's decisions to take up high-profile cases - those involving abortion, speech, religious freedoms, affirmative action, property rights, and other volatile issues - receive intense media attention. As a result, the Court's choices with respect to these high-profile cases "largely determine[] the image that the American people have of their Supreme Court."

1978), in Thurgood Marshall: His SpeEches, Writings, Arguments, Opinions, AND REMINISCENCES 177 (Mark V. Tushnet ed., 2001). Justice Brennan argued that decisionmaking at the threshold stage may be "second to none in importance." William J. Brennan, Jr., The National Court of Appeals: Another Dissent, 40 U. CHI. L. REV. 473, 477 (1973) [hereinafter Brennan, Another Dissent]. See also John R. Schmidhauser, The Supreme CourT 128 (1960) (contending that this "ability to control, to a great extent, both the volume and substance of the litigation which comes before it" is "the most striking attribute of the modern Supreme Court"); Jan Palmer, An Econometric Analysis of the U.S. Supreme Court's Certiorari Decisions, 39 PUB. CHOICE 387, 387 (1982) (noting that "[m]uch of the Court's power rests on its ability to select some issues for adjudication while avoiding others").

5. See, e.g., Edward A. Hartnett, Questioning Certiorari: Some Reflections Seventy-Five Years After the Judges' Bill, 100 COLUM. L. REV. 1643, 1737 (2000) (opining that in some respects "the Supreme Court's power to set its agenda may be more important than what the Court decides on the merits"). The decision not to decide is also important. See Fowler V. Harper \& Arnold Leibowitz, What the Supreme Court Did Not Do During the 1952 Term, 102 U. PA. L. REV. 427, 457 (1954) ("[T] he work which the Supreme Court does not do is as important as the work which it does.").

6. Hartnett, supra note 5, at 1738. The Court's decision in Lawrence v. Texas, 539 U.S. 558 (2003), for example, ignited a debate over gay rights and same-sex marriage.

7. See, e.g., H. W. Perry, JR., Deciding to Decide: Agenda Setting in the United STATES SUPREME COURT 253-58 (1991) (discussing the Court's willingness to take some cases of great societal importance, and its efforts to duck others); Mark Tushnet, The Warren Court as History: An Interpretation, in The WarRen COURT in Historical AND Political Perspective 1, 5 (Mark Tushnet ed., 1993) (describing how the Court denied certiorari on "entirely specious grounds" in Naim v. Naim to avoid hearing a challenge to Virginia's ban on interracial marriage in the tension-filled aftermath of Brown).

8. Brennan, Another Dissent, supra note 4, at 483. Moreover, the decision to review a particular case can have significant ramifications. The specific facts of the case may influence the scope, content, and even the outcome of the Court's opinion on the merits. See PERRY, supra note 7, at 265 (describing the importance to the Justices of finding a "good vehicle" to develop a doctrine in the preferred direction, and their recognition that a case with "bad" facts might cause one to "lose on the merits; or even if one won, ... [to] take doctrine in a way that was undesirable"). The timing of the decision to grant can also be critically important, given that delay may allow for a change in the personnel on the Court, the political climate, or the landscape of precedents. See DENNIS J. Hutchinson, The MAN Who ONCE WAS Whizzer White 408 (1998) (quoting Justice White as saying, "it's perfectly obvious from time to time that a case is being decided in a way quite different 
Much is thus at stake for the Court and for the country at this "preliminary" stage. Yet relatively little is known about how the Justices make their case selection decisions, and almost nothing is known about how they handle high-profile cases. ${ }^{9}$ Before embarking on a closer examination of the Justices' certiorari behavior in high-profile cases, we briefly review case selection in general, discussing the Court's processes and the factors that influence the Justices' decisionmaking.

\section{B. Decisionmaking at the Certiorari Stage}

The central feature of decisionmaking at the certiorari stage is discretion. Three key aspects of the Court's case selection process combine to give the Justices virtually complete and unfettered discretion to control which cases they will hear on the merits. ${ }^{10}$

First, the Court conducts case selection in secret, never publishing the Justices' votes, never explaining the reasons why cases were denied, and only rarely indicating why cases were granted. ${ }^{11}$ Since votes and reasons are not published, no "certiorari precedent" is generated, ${ }^{12}$ which

than it would have been decided if his predecessor were still sitting there"); DORIS MARIE PROVINE, Case Selection in the United States Supreme Court 70 (1980) (describing Chief Justice Warren's concern that “"[d]enials can and do have a significant impact on the ordering of constitutional and legal priorities. Many potential and important developments in the law have been frustrated, at least temporarily, by a denial of certiorari."'); Joan Biskupic, Roberts Steers Court Right Back to Reagan, USA TODAY, June 29, 2007, http://www.usatoday.com/news/washington /2007-06-28-supreme-court-right_N.htm (quoting Justice Breyer who, in reading his dissent from the bench in the 2007 school race cases, said "[i]t is not often in the law that so few have so quickly changed so much").

9. See Friedman, supra note 3, at 294-95 (“One would think legal scholars, quick to say how judges should decide cases, would have more to say about which cases they should decide in the first place.... But for the most part, normative scholars dwell on the cases the Court does hear and entirely neglect how the agenda itself is set."); Sanford Levinson, Strategy, Jurisprudence, and Certiorari, 79 VA. L. REV. 717, 721-22 (1993) (reviewing H. W. PERRY, JR., DeCIDING To DeCIDE: Agenda Setting In the United States Supreme Court (1991)) (suggesting that, in light of "how significant the decision to decide is," constitutional scholars should "be as interested in the processes by which the Justices decide not to engage in articulated decisionmaking as those by which they do").

10. In rare instances, Congress mandates that the Court review certain cases. See, e.g., 28 U.S.C. $\S 1253$ (2000) (appeals in civil injunctive actions from cases before three-judge district courts); 15 U.S.C. $\$ 29$ (a) (2000) (appeals in a limited class of civil antitrust cases).

11. The background section of the Court's opinion on the merits will sometimes briefly indicate why the Court accepted the case for review, but the Court almost never provides substantive reasons. See S. Sidney Ulmer, The Decision to Grant Certiorari as Indicator to Decision "On the Merits", 4 POLITY 429, 432 (1972) (describing a study that demonstrated the rarity with which the Court explained its reasons for granting or denying a case). See generally Hartnett, supra note 5, at 172325 (discussing the effects of secrecy).

12. See John M. Harlan, Manning the Dikes, 13 ReC. Ass'N B. CitY N.Y. 541, 556-57 (1958) (noting the lack of precedential constraint); Hartnett, supra note 5, at 1723 (same). 
relieves the Justices of any external accountability and gives them tremendous discretion in case selection. ${ }^{13}$

Second, decisionmaking at this stage is highly atomistic, with very little discussion or interaction among the Justices. ${ }^{14}$ The Justices initially review the petitions for certiorari in chambers, and unless at least one Justice places the case on the "discuss list," it is denied without any collective deliberation. ${ }^{15}$ In their regular conferences, the Justices as a group do consider the cases on the discuss list, but the norm is simply to vote on the cases without any real discussion of them. ${ }^{16}$ Because the Justices largely make their decisions at this stage in isolation, without having to supply reasons and justifications even to their colleagues, ${ }^{17}$ there is less internal accountability as well, which further enhances the discretion that the Justices enjoy. ${ }^{18}$

13. The Court has justified the secrecy of its process on the basis that the Justices do not have time to explain their decision in each of the thousands of petitions filed per Term, see William $\mathrm{H}$ Rehnquist, Sunshine in the Third Branch, 16 WASHBURN L.J. 559, 561 (1977) (arguing that "there is simply not the time available to formulate statements of reasons why review is denied"), and on the ground that it needs flexibility to wait for the right case, to allow issues to percolate in the lower courts, and to control the size of its docket. See, e.g., Richard L. Revesz \& Pamela S. Karlan, Nonmajority Rules and the Supreme Court, 136 U. PA. L. REV. 1067, 1119 (1988) ("[E]ven once the Court decides that a certain issue is certworthy, it is under no obligation to take the first case that presents it.... The Court's institutional interest, rather than the interest of the parties, is the determining factor....").

14. See, e.g., PERRY, supra note 7, at 147-49 (quoting Justices saying that there is virtually no interchamber discussion on certiorari petitions prior to conference); Gregory A. Caldeira \& John R. Wright, The Discuss List: Agenda Building in the Supreme Court, 24 LAW \& SoC'Y REV. 807, 827 (1990) [hereinafter Caldeira \& Wright, Discuss List] (noting that "the makeup of the discuss list is the summation of a series of individual calculations largely free of collective interaction").

15. See, e.g., PERRY, supra note 7, at 85-91 (describing the "discuss" list and the "dead" list); Caldeira \& Wright, Discuss List, supra note 14, at 809-13 (same); John Paul Stevens, The Life Span of a Judge-Made Rule, 58 N.Y.U. L. REV. 1, 13 (1983) (same); Byron R. White, The Work of the Supreme Court: A Nuts and Bolts Description, 54 N.Y. ST. B. J. 346, 349 (1982) (same). The great majority of the approximately 7000 petitions filed each Term are disposed of this way.

16. See Perry, supra note 7, at 149 . The lack of collective deliberation is presumably due to the intense time pressure that the Justices are under. Chief Justice Hughes, for example, estimated that the Court could allot only three and a half minutes at conference to each of the relatively few cases placed on the discuss list. See Edwin McElwain, The Business of the Supreme Court as Conducted by Chief Justice Hughes, 63 HARV. L. REv. 5, 14 (1949). Professor Hart estimated that each Justice can spend only about twenty minutes in total on each nonfrivolous petition, including all the time needed to read and become familiar with the case materials. See Henry M. Hart, Jr., The Time Chart of the Justices, 73 HARV. L. REV. 84, 87-88 (1959). These time estimates undoubtedly would be shorter today.

17. See PERRY, supra note 7, at 163 (finding that the certiorari process is "relatively atomistic with decisions being made within chambers and the outcome on cert. being primarily the sum of nine individual decision processes").

18. See Brown v. Allen, 344 U.S. 443, 542 (1953) (Jackson, J., concurring) (acknowledging that "neither those outside of the Court, nor on many occasions those inside of it, know just what reasons led six Justices to withhold consent to a certiorari"). 
Third, the Justices themselves wrote the guidelines for considering certiorari petitions, and they provided for complete discretion. The Court's Rule 10 sets out the considerations that the Court takes into account in case selection, which are (in the main) whether the case presents an important federal question and whether there is a conflict in the lower courts. ${ }^{19}$ The rule emphasizes, however, that review "is not a matter of right, but of judicial discretion," and that the criteria provided are "neither controlling nor fully measuring [of] the Court's discretion." 20

With this unfettered discretion, the Justices are free to select cases on any basis, constrained "solely by their individual subjective notions of what is important or appropriate for review by the Court." 21 Nevertheless, at least in the general run of cases, certain factors play a significant and predictable role. Many of the petitions filed are frivolous and are disposed of easily; indeed, Justices have estimated that this is true in about seventy percent of cases. ${ }^{22}$

19. See SuP. CT. R. 10(a)-(c). The full text of the rule states:

Review on a writ of certiorari is not a matter of right, but of judicial discretion. A petition for a writ of certiorari will be granted only for compelling reasons. The following, although neither controlling nor fully measuring the Court's discretion, indicate the character of the reasons the Court considers:

(a) a United States court of appeals has entered a decision in conflict with the decision of another United States court of appeals on the same important matter; has decided an important federal question in a way that conflicts with a decision by a state court of last resort; or has so far departed from the accepted and usual course of judicial proceedings, or sanctioned such a departure by a lower court, as to call for an exercise of this Court's supervisory power;

(b) a state court of last resort has decided an important federal question in a way that conflicts with the decision of another state court of last resort or of a United States court of appeals;

(c) a state court or a United States court of appeals has decided an important question of federal law that has not been, but should be, settled by this Court, or has decided an important federal question in a way that conflicts with relevant decisions of this Court.

A petition for a writ of certiorari is rarely granted when the asserted error consists of erroneous factual findings or the misapplication of a properly stated rule of law.

20. See SuP. CT. R. 10; see also PERRY, supra note 7, at 221 ("Fundamentally, the definition of "certworthy" is tautological; a case is certworthy because four [J]ustices say it is certworthy."); Levinson, supra note 9, at 736 ("[I]t seems difficult indeed to read the Court's own Rule 10 as anything other than an invitation to balancing, to the making of 'political choice(s)' about what is 'important' enough.”).

21. Eugene Gressman, The National Court of Appeals: A Dissent, 59 A.B.A. J. 253, 255 (1973); see also WiLliam O. DOUGLAS, THE COURT YeARS 1939-1975, at 175-76 (1980) (stating that "the job here [deciding whether to grant plenary review] is so highly personal, depending on the judgment, discretion, and experience and point of view of each of the nine of us"); WILLIAM H. REHNQUIST, THE SUPREME COURT: HOW IT WAS, How IT IS 265 (1987) ("Whether or not to vote to grant certiorari strikes me as a rather subjective decision, made up in part of intuition and in part of legal judgment.").

22. See Brennan, Another Dissent, supra note 4, at 479 (noting that "the Court is unanimously 
In the remaining group of cases - the potentially meritorious casesthree indicators of "importance" (the key criteria in the Court's Rule 10) figure large. First, if a genuine conflict exists between the lower courts or between the lower court and a Supreme Court precedent, the likelihood that the Court will grant review increases markedly. ${ }^{23}$ Second, if the federal government seeks review, asserting that it is adversely affected by a lower court decision or by the need to respond to conflicting decisions in different regions of the country, the Court is far more likely to grant the case. ${ }^{24}$ Third, if amicus curiae briefs are filed in support of (or even in opposition to) the petition for review, the probability that the Court will grant review increases dramatically, presumably because amicus briefs signal the Justices that the case has broader social or economic significance. ${ }^{25}$

of the view in 70 percent of all docketed cases, that the questions sought to be reviewed do not even merit conference discussion"); White, supra note 15, at 349 ("About 70 percent of the cases filed do not make the discuss list and are unanimously denied.").

23. See Gregory A. Caldeira \& John R. Wright, Organized Interests and Agenda Setting in the U.S. Supreme Court, 82 AM. POL. SCI. REV. 1109, 1120 (1988) [hereinafter Caldeira \& Wright, Organized Interests] ("Whenever actual conflict was present, the likelihood that certiorari was granted jumped dramatically."); David R. Stras, The Supreme Court's Gatekeepers: The Role of Law Clerks in the Certiorari Process, 85 TEX. L. REV. 947, 981-83 (2007) (reviewing TODD C. PEPPERS, Courtiers of the Marble Palace: The Rise and Influence of THE Supreme Court LAW CLERK (2006) and ARTEMUS WARD \& DAVID L. WEIDEN, SORCERERS' APPRENTICES: 100 YEARS OF LAW CleRKS AT THE UNITED STATES SuPREME COURT (2006)) (showing that approximately $70 \%$ of cases granted in the 2003-2005 Terms involved a conflict among the lower courts); S. Sidney Ulmer, The Supreme Court's Certiorari Decisions: Conflict as a Predictive Variable, 78 AM. POL. SCI. REV. 901, 906-11 (1984) [hereinafter Ulmer, Conflict as Predictive Variable] (demonstrating a significant relationship between the grant of certiorari and the presence of genuine intercircuit conflict or conflict with Supreme Court precedent); S. Sidney Ulmer, Conflict with Supreme Court Precedents and the Granting of Plenary Review, 45 J. POL. 474, 474-77 (1983) (finding that the Court is more likely to grant review in cases where the ruling conflicted with Supreme Court precedent).

24. The Court grants more than fifty percent of the Solicitor General's petitions for review, whereas it grants only about three percent of paid petitions filed by other parties. See ROBERT L. Stern et AL., Supreme COURT Practice 164 \& n.6 (7th ed. 1993) [hereinafter STERN \& Gressman]; see also Rebecca Mae Salokar, The Solicitor General: The Politics of LAW 25 (1992) (between 1959 and 1989, the Solicitor General was successful in obtaining plenary review $69.78 \%$ of the time, whereas private litigants were successful only $4.9 \%$ of the time); Caldeira \& Wright, Discuss List, supra note 14, at 828 (finding that the presence of the United States as petitioner is a key determinant in the decisional calculus).

The federal government's success is also attributable to the Solicitor General's restraint in seeking review, and to the expertise and quality of the lawyers in his office. See, e.g., RICHARD A. Posner, The Federal Courts: Challenge AND REFORM 142 (1996) (describing the Solicitor General's office as “superbly staffed”); STERN \& GRESSMAN, supra, at 164 (Solicitor General's success "is due both to the fact that government cases are likely to be of more general public importance and to the strictness with which the office screens the cases lost by the government below before deciding to petition for certiorari.").

25. See Caldeira \& Wright, Organized Interests, supra note 23, at 1111-12. Based on data from the 1982 Term, the authors showed that when a case involves an actual conflict or when the United States is the petitioner, the filing of just one amicus brief in support of the petition increases 
The Justices' individual views on other, more jurisprudential considerations also influence and guide their decisions on which cases present an "important" question. Thus, for example, a Justice's views on whether the Court should serve as an engine of social change will influence how eagerly (or hesitantly) that Justice reaches out for culturally or politically sensitive cases. ${ }^{26}$ Similarly, a Justice's views on the importance of achieving uniformity in federal law will affect his or her inclination to vote to grant cases on that basis. ${ }^{27}$ Many other factors, such as his or her views on how the Court can best supervise the lower courts through precedent, ${ }^{28}$ special interest in a particular area of the law, ${ }^{29}$ concern about the size of the docket, ${ }^{30}$ and sense about whether the

the likelihood that the Court will grant certiorari by forty to fifty percent, and the filing of two or three amicus briefs increases the likelihood even more. See id. at 1119,1122. Amicus briefs help to flag importance because they are expensive to prepare $(\$ 15,000$ to $\$ 20,000$ in 1988 and undoubtedly more today). See id. at 1112.

26. Justice Brennan, for example, felt strongly that the Court should promote social change. See, e.g., Kim IsAAC EISLER, A JuSTICE fOR All: William J. BRENNAN, JR., AND THE DECISIONS THAT TRANSFORMED AMERICA 164 (1993) (Justice Brennan took "an active leadership role in trying to find cases that would promote his reforms."). Justice Harlan, on the other hand, believed that the Court had no such mandate. See Reynolds v. Sims, 377 U.S. 533, 624-25 (1964) (Harlan, J., dissenting) ("The Constitution is not a panacea for every blot upon the public welfare, nor should this Court, ordained as a judicial body, be thought of as a general haven for reform movements."). See generally Cordray \& Cordray, Philosophy of Certiorari, supra note 1, at 435-41 (discussing this variable in more detail).

27. While all of the Justices agree that resolving conflicts among the lower courts is an important function of the Court, see, e.g., Sandra Day O'Connor, Our Judicial Federalism, 35 CASE W. RES. L. REV. 1, 5 (1984) (noting that "the most commonly enunciated reason for granting review in a case is the need to resolve conflicts"), there is wide divergence in the Justices' views on how much emphasis to give this variable. Justice White, for example, fervently argued that a principal task of the Court is "to provide some degree of coherence and uniformity in federal law throughout the land," White, supra note 15, at 349, whereas Justice Stevens saw no need for the Court to "'act to eradicate disuniformity as soon as it appears." California v. Carney, 471 U.S. 386, 400 n.11 (1985) (Stevens, J., dissenting) (quoting Samuel Estreicher \& John E. Sexton, A Managerial Theory of the Supreme Court's Responsibilities: An Empirical Study, 59 N.Y.U. L. Rev. 681, 716 (1984)). See generally Cordray \& Cordray, Philosophy of Certiorari, supra note 1, at 441-49 (discussing this variable in more detail).

28. See Cordray \& Cordray, Philosophy of Certiorari, supra note 1, at 441-51 (discussing how a Justice's view of the proper mode of decisionmaking can influence his or her decisions about case selection).

29. See PERrY, supra note 7, at 262-63 (describing various interest areas for different Justices); Arthur D. Hellman, Case Selection in the Burger Court: A Preliminary Inquiry, 60 NOTRE DAME L. REV. 947, 1048-49 (1985) (opining that up to half of the plenary docket is shaped by the particular interests and inclinations of the Justices then sitting on the Court).

30. See Provine, supra note 8, at 120 (concluding that the bulk of Justices during the Burton era "failed to vote often for review less because they were satisfied with lower-court results than because they felt constrained by the limited capacity of the Court for judicial decision making"); William J. Brennan, Jr., Some Thoughts on the Supreme Court's Workload, 66 JUDICATURE 230, 231 (1983) [hereinafter Brennan, Thoughts on Workload] ("There is a limit to human endurance, and with the ever increasing complexity of many of the cases that the Court is reviewing in this modern day, the number 150 taxes that endurance to its limits."). 
case presents a "good vehicle" for resolving the issue ${ }^{31}$ can also affect a Justice's case selection decisions.

Ideological and strategic considerations also play a role in decisionmaking on certiorari, at least in some cases. A Justice is more likely to vote to grant a case when he or she seeks to reverse the lower court. $^{32}$ In many instances, the Justices' own ideological preferences surely influence their views on whether a case was rightly or wrongly decided, making ideology a factor in the decisionmaking. ${ }^{33}$ Just as surely, however, in some instances (such as tax and patent law cases) a Justice's inclination to reverse is based not on ideology, but rather on purely legal considerations, leaving unclear the extent to which ideology plays a role. ${ }^{34}$

To varying degrees, the Justices also engage in a strategic voting calculation at the certiorari stage, looking beyond whether the case deserves full review to whether their views will prevail on the merits. ${ }^{35}$

31. Various problems can prevent a case from being a good vehicle, ranging from potential jurisdictional problems to bad facts. See PERRY, supra note 7, at 265 (describing the importance to the Justices of finding a "good vehicle" to develop a doctrine in the preferred direction).

32. See Jan Palmer, The Vinson Court Era: The Supreme Court's Conference Votes 59-62 (1990) (finding a statistically significant relationship between voting to grant certiorari and ultimately voting to reverse for all Justices during the Vinson era); PROVINE, supra note 8 , at 107-10 (finding that all Justices during the Burton period were more likely to vote to reverse a case that they voted to review); Robert L. Boucher, Jr. \& Jeffrey A. Segal, Supreme Court Justices as Strategic Decision-Makers: Aggressive Grants and Defensive Denials on the Vinson Court, 57 J. POL. 824, 832 (1995) (finding "overwhelming evidence that [J]ustices are reversal minded in their certiorari votes"); Saul Brenner \& John F. Krol, Strategies in Certiorari Voting on the United States Supreme Court, 51 J. POL. 828, 833 (1989) (finding that, over seven terms of the Vinson, Warren, and Burger Courts, Justices who voted to reverse on the merits had a grant rate of $77.7 \%$, whereas Justices who voted to affirm had a grant rate of $59.1 \%$ ).

33. See Lawrence Baum, Case Selection and Decisionmaking in the U.S. Supreme Court, 27 LAW \& SOC'Y REV. 443, 454-56 (1993) (arguing that, at the Supreme Court level, where the result is often not dictated by precedent, a preference for error correction likely has a strong ideological component); John F. Krol \& Saul Brenner, Strategies in Certiorari Voting on the United States Supreme Court: A Reevaluation, 43 W. PoL. Q. 335, 335 n.1 (1990) (same); see also Virginia C. Armstrong \& Charles A. Johnson, Certiorari Decisions by the Warren \& Burger Courts: Is Cue Theory Time Bound?, 15 POLITY 141, 149 (1982) (finding that in civil liberties and economic cases, the conservative Burger Court "consistently accepted more petitions involving liberal lower court decisions than those involving conservative lower court decisions"); Caldeira \& Wright, Organized Interests, supra note 23, at 1120 (finding a "clear tendency" by the Burger Court to select cases decided liberally below); Kevin H. Smith, Certiorari and the Supreme Court Agenda: An Empirical Analysis, 54 OKLA. L. REV. 727, 759, 769 (2001) (finding that the predominantly conservative Court from 1981-1987 was 5.5 times more likely to grant a case if the decision below was liberal).

34. See Frank B. Cross, The Justices of Strategy, 48 DuKE L.J. 511, 542 (1998) (reviewing LEE EPSTEIN \& JACK KNIGHT, THE CHOICES JUSTICES MAKE (1998)) (noting that the Court regularly grants "cases that lack ideological or political import" and suggesting that this demonstrates "the power of legal concerns").

35. See Gregory A. Caldeira et al., Sophisticated Voting and Gate-Keeping in the Supreme Court, 15 J.L. ECON. \& ORG. 549, 561-71 (1999) [hereinafter Caldeira et al., Sophisticated Voting] (contending that strategic voting is routine and substantially impacts the Court's docket); see also 
Perhaps the most common forms of strategic voting are the "defensive denial," where a Justice votes against his or her own preference to grant a case in order to fend off an undesirable result on the merits, and the "aggressive grant," where a Justice votes to grant a case not to reverse, but rather to affirm and thus give the Supreme Court's imprimatur to a desirable result below. ${ }^{36}$ Yet another strategic behavior is when a Justice seeks a "good vehicle" - a case with a good set of facts - in order to enhance his or her chances of driving doctrine in a particular way or convincing a swing Justice to join. ${ }^{37}$

Although there is disagreement about whether the Justices engage in strategic voting, recent empirical studies provide strong evidence that they do $^{38}$ and the Justices themselves have acknowledged as much. ${ }^{39}$ There is also growing attention to how effectively the Court may "signal" its interest in particular issues, and how this signaling may encourage other parties, including litigants, lower courts, and officials in the other branches and levels of government, to influence the legal and policy agenda on those issues. ${ }^{40}$ But the real (and yet unresolved) issue

Boucher \& Segal, supra note 32 , at 830-32, 836 (arguing that Justices who wish to affirm the decision below have less to gain and more to lose, so more carefully calculate the chances of winning on the merits than reverse-minded Justices); Saul Brenner, The New Certiorari Game, $41 \mathrm{~J}$. POL. 649, 651-55 (1979) (same); Palmer, supra note 4, at 393-96 (finding a positive relationship between voting to grant certiorari and voting with the majority on the merits in a study of 512 cases from the 1947-1956 Terms).

36. See, e.g., Lee Epstein \& Jack Knight, The Choices Justices MaKe 80 (1998) (describing aggressive grants and defensive denials); PERRY, supra note 7, at 198-212 (same); Caldeira et al., Sophisticated Voting, supra note 35, at 558 (defining these terms and giving examples).

37. See PERrY, supra note 7, at 281-82 (discussing the importance Justices attach to finding a good vehicle).

38. See, e.g., Caldeira et al., Sophisticated Voting, supra note 35, at 553-71 (providing strong empirical evidence that strategic voting occurs regularly and substantially affects the composition of the Court's plenary docket); Lee Epstein et al., Dynamic Agenda-Setting on the United States Supreme Court: An Empirical Assessment, 39 HARV. J. ON LEGIS. 395, 405 (2002) (opining that, although the debate over whether the Justices vote strategically will continue, "the evidence, especially that offered by the most recent (and sophisticated) studies, tips the scales substantially in favor of the strategic camp"). But cf. PROVINE, supra note 8, at 125-30, 172 (arguing that the Burton era Justices did not consider the likely result on the merits in case selection); Krol \& Brenner, supra note 33, at 340-42 (doubting whether the Vinson Court, in general, considered likely outcome in case selection, but recognizing that individual Justices may have done so).

39. See PERRY, supra note 7, at 198-202 (describing how each of the five Justices he interviewed acknowledged - with varying degrees of approval-use of the defensive denial); Cordray \& Cordray, Philosophy of Certiorari, supra note 1, at nn.122-24 and accompanying text (discussing various Justices' own observations on use of the defensive denial).

40. See, e.g., VAnessa A. Baird, Answering the Call of the Court: How Justices and LitigANTS SET THE SUPREME COURT AGENDA 4 (2007) ("The main argument is that the incentive to support litigation in particular policy areas varies over time in accordance with litigants' changing perceptions of Supreme Court [J] ustices' policy priorities."). See generally id. passim (discussing and documenting evidence to support this main argument). 
is how rare or how pervasive ideological and strategic factors are in the individual Justices' decisionmaking when voting on certiorari. ${ }^{41}$

It would seem natural that the extent to which, and the situations in which, an individual Justice acts strategically are closely linked to how strongly he or she feels about the issue at stake. ${ }^{42}$ In other words, the more intensely a Justice cares about a particular issue or doctrine, the more likely it is that the ultimate resolution on the merits will matter to the Justice, causing that factor to play a larger role in his or her certiorari decisions in those cases.

In the next section, we examine this assumption - that the Justices act more strategically in cases about which they feel strongly. To do this, we identified the "high-profile" cases in each Term from the 1983 Term through the 1993 Term. In determining which cases belonged in the high-profile category, we used several sources. First, we included every case designated as a "major decision" in the Guide to the U.S. Supreme Court and The Supreme Court Compendium. ${ }^{43}$ Second, for each Term, we evaluated all of the cases that either were included in the Harvard Law Review's recap of the "leading cases" of the Term ${ }^{44}$ or were discussed in the New York Times' summary of the Term. ${ }^{45}$ From this larger list of cases, we treated as "high-profile" those cases that involved issues of significant social or political controversy. In particular, we included cases in all of the following categories: substantive due process/abortion; religion; free speech (political, libel, obscenity, free press); federalism; separation of powers; takings; race and

41. Some scholars contend that use of such considerations is rare. See, e.g., ProvinE, supra note 8, at 125-30, 172 (contending that the Burton era Justices did not act strategically in case selection). Others contend that consideration of ideological and strategic considerations are matters of routine. See, e.g., Caldeira et al., Sophisticated Voting, supra note 35, at 553-71 (opining that strategic voting occurs regularly). We have argued that, while there is a significant merits-oriented component to the Justices' decisionmaking, jurisprudential and administrative considerations play a substantial role as well. See Margaret M. Cordray \& Richard Cordray, Strategy in Supreme Court Case Selection: The Relationship Between Certiorari and the Merits, 69 OHIO ST. L.J. 1, 16-30 (2008) [hereinafter Cordray \& Cordray, Strategy in Case Selection].

42. See, e.g., PERRY, supra note 7, at 274-82 (arguing that where a Justice cares deeply about a particular issue, "the first thing that the [J]ustice does is try to make an assessment of whether or not he will win on the merits," but in other cases, it is more typical to employ a variety of procedural "gatekeeping" criteria).

43. See LeE EPSTEIn et AL., The Supreme Court Compendium: Data, Decisions, And DEVELOPMENTS 124-33 tbl.2-12 (3d ed. 2003) [hereinafter SuPREME COURT COMPENDIUM]; DAVID G. SAvage, 2 Guide to the U.S. Supreme COURT 1239-47 (4th ed. 2004). We were unable to locate any information on the Justices' votes in one of these "major decisions," Herrera v. Collins, 506 U.S. 390 (1993), so it is not included in our dataset.

44. E.g., Leading Cases, 106 HARV. L. REV. 163 (1992).

45. E.g., Linda Greenhouse, A Divided Supreme Court Ends the Term with a Bang, N.Y. TimeS, July 1, 1990, at E3. 
sex discrimination; Eighth Amendment (sentencing, death penalty); Fourth Amendment (exclusionary rule); and Fifth/Sixth Amendment (Miranda). Because there were so many cases in the death penalty and free speech areas that involved insignificant issues at the margins of those constitutional provisions, we eliminated cases from those categories that clearly appeared to present technical issues, rather than issues of social or political significance. ${ }^{46}$ Approximately fifteen cases per Term fell within the high-profile category (the totals ranged from a low of ten in the 1991 Term to a high of twenty in the 1988 Term); a list of these cases is provided in Appendix A, along with the votes cast by each of the Justices in all of those cases. ${ }^{47}$

\section{VOTING ON CERTIORARI IN HIGH-PROFILE CASES}

Each individual Justice has a complex and highly individualized process for culling out those special cases that warrant plenary review. Our question is whether, consciously or subconsciously, they treat highprofile cases differently from the other cases in the select group of nonfrivolous certiorari petitions. Although the Justices are relatively isolated from the daily concerns and struggles of most Americans, it seems certain that they not only are aware of which issues lie at the heart of the country's social and political agenda, but have their own deeply held views about those issues. ${ }^{48}$ What we seek to assess, as far as the Justices' voting records permit, is how the Justices approach the cases that present these issues.

46. There are two potential problems with our selection of the high-profile cases. First, the year end summaries from both the New York Times and Harvard Law Review are created after the cases have been decided, and the editors' decisions on which cases to include are likely influenced by the results in those cases. The Justices, of course, are looking at the cases much earlier, and their perceptions of which cases are high-profile at the certiorari stage may not line up exactly with which cases turn out to be high-profile cases at the end of the Term. Second, eliminating cases based on whether they presented merely technical issues introduces an element of subjectivity into the creation of the comparison sets. We felt it was essential, however, to make this additional cut in order to create a set of cases that met our definition. We designated the set of high-profile cases before doing any of the empirical analysis to ensure that we did not manipulate the data in any way to achieve particular results.

47. Interestingly, although the size of the Court's docket declined markedly in the 1990s, the number of cases that fell within the high-profile category each Term remained relatively steady. The specific numbers are as follows: $1993-11 ; 1992-17 ; 1991-10 ; 1990-16 ; 1989-13 ; 1988-20$; $1987-18 ; 1986-11 ; 1985-18 ; 1984-13 ; 1983-14$.

48. See PERRY, supra note 7, at 260 (noting that the Justices "do read the newspapers, and they do live in Washington, and they undoubtedly know when the resolution of an issue needs the imprimatur of the Supreme Court"); $i d$. at 280 (recognizing that "those cases about which a [J]ustice would care strongly are often ones of great importance"). 
One possibility is that the Justices behave even more strategically than usual in such cases to achieve the results that they desire. Individual passions run high when issues such as abortion, religious freedom, gay rights, and affirmative action are involved. With regard to such issues, each Justice generally has clearly formed views and a keen interest in seeing those views reflected in legal doctrine. ${ }^{49}$ Moreover, each Justice usually is able to develop a strong sense of the other Justices' positions, and how the Court will likely resolve the case on the merits. ${ }^{50}$ There would thus seem to be strong temptation to vote based on the expected outcome, given the ideological stakes and the ease of casting a forwardlooking vote at the threshold stage.

Based on his extensive interviews of five Justices and sixty-two former law clerks, Professor H. W. Perry concluded that the Justices do act differently and more strategically in ideologically laden, socially important cases. Perry found that in most cases the Justices follow a "jurisprudential mode" of decisionmaking, where in essence they take each nonfrivolous petition through a series of gates, considering whether there is a conflict in the circuits, how important the issue is, how urgent resolution of the issue is, and whether the particular case is a good vehicle substantively and procedurally. ${ }^{51}$

However, Perry contended that in those cases where a Justice cares deeply about a particular issue - as is almost invariably true in the highprofile cases - he or she tends to employ a far more outcome-oriented decisional calculus: "When entering the outcome decision mode, the first thing that the $[\mathrm{J}]$ ustice does is try to make an assessment of whether or

49. See, e.g., Letter from Justice Felix Frankfurter to the Chief Justice and Associate Justices of the Supreme Court of the United States of America (Sept. 28, 1962), in 371 U.S. ix, x (1962) ("The nature of the issues which are involved in the legal controversies that are inevitable under our constitutional system does not warrant the nation to expect identity of views among the members of the Court regarding such issues, nor even agreement on the routes of thought by which decisions are reached."); Lewis F. Powell, Jr., What Really Goes on at the Supreme Court, 66 A.B.A. J. 721, 722 (1980) ("We do indeed have strong professional differences about many of our cases. . . We fight hard for our professional views."); William H. Rehnquist, The Supreme Court: Past and Present, 59 A.B.A. J. 361, 363 (1973) ("When reasonable minds may and do frequently disagree as to the proper interpretation of a constitutional provision, there is a natural tendency on the part of a [J] ustice to want to state his own views if they differ significantly from those of the majority of his brethren.").

50. See, e.g., Lewis F. Powell, Jr., Myths and Misperceptions About the Supreme Court, 48 N.Y. ST. B.J. 6, 10 (1976) ("Of course, Justices differ in their perceptions of issues, in what is sometimes called their judicial philosophy, and in basic assumptions as to the meaning of some provisions of the Constitution. On some of these issues, depending on the context, one may rationally guess as to how a brother [J]ustice will vote."). He went on to caution, however, that "on most of the closest issues advance predictions are hazardous, even for those of us who serve together." Id.

51. See PERRY, supra note 7, at 277-79 (discussing the Court's decision process with a graphical representation). 
not he will win on the merits. If he thinks he will not, he will vote to deny the case." 52 If, on the other hand, "the [J]ustice thinks he will win on the merits, and if [the case] allows him to move doctrine in the way he wishes," then the Justice will vote to grant. ${ }^{53}$ Professor Ulmer also has presented evidence that the Justices' strategy depends on the content of the issue, with some cases merely requiring a legal resolution and others implicating concerns from a broader policy perspective. ${ }^{54}$

A second possibility, however, is that the Justices act with a greater institutional sense of the Supreme Court's role in the high-profile cases. ${ }^{55}$ This possibility is almost diametrically opposed to the first: rather than voting strategically with a view to advancing their own social and political agendas, the core factor in the Justices' decisionmaking is the importance of the case to the Supreme Court's institutional standing and integrity. Each individual Justice's particular conception of the Supreme Court's essential role and responsibilities is no doubt somewhat distinct and influenced by many factors. ${ }^{56}$ But the Justices nevertheless must

52. Id. at 280. Perry provided a caveat, however:

The one mitigating situation in this outcome-driven behavior would be if it would be institutionally irresponsible not to take the case; for example, if the [Solicitor General] convinces [the Justice] that refusal to decide the issue now would be disastrous, or if it is a decision where the Supreme Court simply must act. An example of the latter might be Id. something like the Nixon tapes case.

53. Id. at 265; see also id. at 275, 279-82 (describing the "outcome mode" decision model and noting that a Justice will flip over to this model whenever he or she cares strongly about an issue, whether the case involves a politically sensitive issue or a more mundane issue in an area that happens to matter deeply to that particular Justice). Justices occasionally acknowledge using a similar approach on the merits. See, e.g., Letter from Harlan F. Stone to Benjamin Cardozo (Jan. 19, 1932) (on file in Harlan F. Stone Papers, Library of Congress) ("I have felt called upon to dissent so much in cases involving constitutional questions that I usually let private law decisions with which I do not agree pass without noting an objection."), quoted in WALTER F. MURPHY, ELEMENTS OF JUDICIAL STRATEGY 62 n.* (1964).

54. See Ulmer, Conflict as Predictive Variable, supra note 23, at 901-11 (supporting the view that the Justices employ this dichotomous approach).

55. Chief Justice Roberts, for instance, has been an apostle for this approach in many of his public statements about the Supreme Court. See, e.g., Jeffrey Rosen, Roberts's Rules, THE ATLANTIC 104, 106 (Jan./Feb. 2007), available at http://www.theatlantic.com/doc/200701/johnroberts ("Instead of nine [J]ustices moving in nine separate directions, Roberts said, "it would be good to have a commitment on the part of the Court to acting as a Court, rather than being more concerned about the consistency and coherency of an individual judicial record."'); $i d$. at 113 ("In other words, Roberts said, judicial temperament involves a judge's willingness to 'factor in the Court's institutional role,' to suppress his or her ideological agenda in the interest of achieving consensus and stability.").

56. This conception has been described by the Justices themselves as being highly subjective in its nature. As Justice Harlan stated, whether a case is important enough to merit the Court's plenary review "[f]requently . . . is more a matter of 'feel' than of precisely ascertainable rules." Harlan, supra note 12, at 549. Likewise, Justice Douglas observed that these matters are "so highly personal, depending on the judgment, discretion, and experience and point of view of each of the nine of us." Douglas, supra note 21, at 175-76. See generally Cordray \& Cordray, Philosophy of 
recognize the disproportional importance of these cases to the Court's image with the American public and its authority within our tripartite system of government. ${ }^{57}$

To the extent these considerations carry weight, they would tend to lead the Justices to vote non-strategically in the high-profile cases. Rather than asking whether he or she will win on the merits, the Justice instead would ask whether it is necessary and expected that the United States Supreme Court should decide this case or this issue at this time. Although the internal dynamics of the Justices' conference are largely unknown, it is quite plausible that the importance of these high-profile cases to the Court as an institution may cause the Justices to spend more time in conference deliberating as a body over whether to grant or deny them. This additional collective consideration as a Court, rather than the usual tallying of predetermined votes that were reached in relative isolation, might also lead to greater consensus about the need for Supreme Court review. ${ }^{58}$

Professor Doris Marie Provine has championed the view that the Justices' sense of judicial responsibility leads them to act nonstrategically in case-selection decisions. Noting that the certiorari process allows the Justices virtually limitless discretion, she nonetheless argued that "members of the Supreme Court share a conception of their role which prevents them from using their votes simply to achieve policy preferences." 59 Based on her examination of Justice Burton's papers, Provine found that the Justices' voting records on certiorari indicated "that the $[\mathrm{J}]$ ustices selected cases with something more than the result they desired on the merits in mind. More particularly, these voting patterns seem to reflect judicial sensitivity to the role of the Supreme

Certiorari, supra note 1, at 416-51 (discussing various factors that influence individual Justices' views on the proper role of the Court and how they affect decisionmaking at the certiorari stage).

57. See, e.g., PERRY, supra note 7, at 253-60 (discussing the Court's willingness to take some cases of great societal importance, and its efforts to duck others); Brennan, Thoughts on Workload, supra note 30, at 235 ("The choice of issues for decision largely determines the image that the American people have of their Supreme Court."); Hartnett, supra note 5, at 1738 (noting perhaps "the most significant impact of Supreme Court decisions is to increase the political salience of the issues decided - regardless of which way the Court decides the issues").

58. See, e.g., Rosen, supra note 55, at 110 ("Rehnquist was famous for running a briskly efficient conference, but Roberts said that his own vision of unanimity sometimes requires longer discussions. 'There's a lot less flexibility once something is in writing,' he said."). A generation before, Justice White had offered his own description of conference deliberations on the Burger Court as "straightforward affairs," and whether "we are discussing certioraris or argued cases ... [t]here is a good deal of give and take in the process, and by the time that everyone has had his say, the vote is usually quite clear," though it is unclear how often the discussion may have fostered any greater consensus. White, supra note 15 , at 383 .

59. PROVINE, supra note 8, at 174. 
Court on the merits." 60 While Provine's analysis was not focused on high-profile cases, and while she recognized the possibility that "some [J] ustices calculate outcomes in cases that are particularly important to them," 61 she strongly advocated that "the [J]ustices' perceptions of a judge's role and of the Supreme Court's role in our judicial system" are central to their case selection decisions. ${ }^{62}$ Professor Walter F. Murphy, in his classic study of judicial strategy, likewise observed:

It would be ... difficult to deny that much of the force of self-restraint can be traced to individual Justices' concepts of their proper role in American government, to a realization that they are equipped by training, availability of information, and choice of legal remedies to offer only partial solutions to many problems and no solution at all to many others. ${ }^{63}$

Yet a third possibility is that the Justices treat case selection in highprofile cases in the same manner that they treat all other cases. The Justices' sense of the judicial role, as opposed to the institutional role of the Supreme Court, might lead them to apply the same standards through the same selection process in every case, whether the issue involves patent law, the tax code, abortion, or affirmative action. ${ }^{64}$ In other words, the Justices may use the same blend of strategic and institutional factors in high-profile cases as they do in more ordinary cases, rather than giving greater emphasis to strategic (or institutional) considerations. At a minimum, the Justices may feel an obligation to try to follow their usual procedures in these cases, which may affect their case selection decisions. ${ }^{65}$

\footnotetext{
60. Id. at $124-25$.
}

61. Id. at 129 .

62. Id. at 6 .

63. MURPHY, supra note 53, at 29.

64. See, e.g., PERRY, supra note 7, at 3 ("Political scientists do often over-politicize the Court, disregarding many of the very real constraints upon it."); C. Herman Pritchett, The Development of Judicial Research, in Frontiers OF JUdicIAL RESEARCH 42 (Joel B. Grossman \& Joseph Tanenhaus eds., 1969) ("Judges make choices, but they are not the 'free' choices of congressmen. ... Any accurate analysis of judicial behavior must have as a major purpose a full clarification of the unique limiting conditions under which judicial policy making proceeds.").

65. See, e.g., BAIRD, supra note 40, at 83-120 (discussing the "time-lapsed" attention that the Supreme Court pays to prioritized policy areas and suggesting that the Justices' concerns about the Court's institutional legitimacy leads them to avoid issuing important policy-shifting decisions in the same substantive area in rapid succession). In another passage, she suggests as an alternative that "[p]erhaps the conclusion to draw from this debate is that [J] ustices would like to have it both ways - to implement their policy preferences while trying to maintain their appearance of being constrained." Id. at 30 . 
To gain a better sense of how the Justices approach the cases that present high-profile issues, we collected information on the Justices' certiorari votes from the private papers of Justices Blackmun, Brennan, and Marshall for the 1983 Term through the 1993 Term. We used this information to make four types of comparisons between the Justices' behavior in high-profile cases and their behavior in low-profile cases. ${ }^{66}$ First, we compared the frequency with which each Justice voted to grant high-profile cases as opposed to low-profile cases. Second, we compared the degree of unanimity (and divisiveness) with which the Court granted high-profile cases as opposed to low-profile cases. Third, we looked at whether Justices who are ideologically aligned on the merits tend to vote together more frequently on certiorari in high-profile cases as opposed to the full set of cases granted (and, conversely, whether Justices who are ideologically opposed on the merits tend to vote together less frequently on certiorari in high-profile cases as opposed to the full set of cases granted). Fourth, for five of the Terms in our dataset, we tracked how each Justice voted on certiorari and then on the merits, to assess whether the Justices behave more strategically in high-profile versus low-profile cases. As we will explain further, we did so by considering whether each Justice tended to "win" more frequently in high-profile cases, and also whether each Justice tended to vote to reverse more frequently in such cases.

In comparing the frequency with which each Justice voted to grant cases, the degree of unanimity in voting on certiorari, and the Justices' voting alignments, we saw strong evidence that the Justices' tendency to vote with an eye to the merits is even more pronounced in high-profile cases, but the results also suggested that the Justices are voting at least in some cases based on a sense of the Court's institutional responsibility. In the five Terms for which we tracked the Justices' voting behavior from certiorari through the merits, we found that in the cases the Justices voted to grant, they tended to vote to reverse with the same frequency in high-profile versus low-profile cases. But the Justices tended to win less often in high-profile cases that they voted to grant than they did in lowprofile cases that they voted to grant. Although the reasons for this voting behavior are not entirely clear, we think it provides some further evidence that the Justices' sense of the Court's institutional responsibilities has an effect on their decisionmaking in high-profile cases.

66. For purposes of our analysis, we treated all cases that were granted for plenary review but were not high-profile cases as "low-profile" cases. See supra notes 43-46 and accompanying text (describing the method we used to identify the high-profile cases in each Term). 


\section{A. Grant Rate in High-Profile vs. Low-Profile Cases}

To determine the Justices' grant rates (i.e., the frequency with which each Justice voted to grant certiorari), we calculated the grant rate for each Justice based on the percentage of votes that he or she cast to grant certiorari $^{67}$ in the total universe of cases that were granted and set for plenary review on the merits. ${ }^{68}$

To gauge the ideological preferences of the Justices, we used data from the Supreme Court Compendium on the percentage of civil liberties cases in which each Justice voted in a liberal direction. ${ }^{69}$ The Justices' scores fell roughly into four categories: liberal (above 75\%), moderateliberal (between $75 \%$ and 55\%), moderate-conservative (between 55\% and $35 \%$ ), and conservative (below 35\%). ${ }^{70}$ Not surprisingly, during the Terms that they participated in our dataset (1983-1993), Justices Marshall and Brennan fell in the liberal category; Justices Stevens, Blackmun, and Ginsburg fell in the moderate-liberal category; Justices Souter, Kennedy, Powell, and O'Connor fell in the moderateconservative category; and Justices White, Scalia, and Thomas, and Chief Justices Burger and Rehnquist fell in the conservative category. ${ }^{71}$

Based on the Justices' grant rates in the full set of cases that the Court granted for plenary review, it appears that the Justices' strategic

67. We included all "Join-3" votes, because they function as votes to grant. See generally Margaret Meriwether Cordray \& Richard Cordray, The Supreme Court's Plenary Docket, 58 WASH. \& LEE L. Rev. 737, 780-81 (2001) [hereinafter Cordray \& Cordray, Plenary Docket] (discussing Join-3 votes). A Join-3 vote is a vote to grant review if at least three other Justices vote in favor of review. See David M. O'Brien, Join-3 Votes, the Rule of Four, the Cert. Pool, and the Supreme Court's Shrinking Plenary Docket, 13 J.L. \& POL. 779, $788-99$ (1997) (describing the Justices' use of the Join-3 vote).

68. We calculated each Justice's grant rate for each Term, then averaged the per-Term numbers to arrive at an overall grant rate for each Justice.

Because so many petitions are frivolous, and because all of the Justices simply vote to deny them, considering the Justices' grant rates based on the percentage of votes cast in all cases filed would produce extremely low grant rates and a false sense of similarity among the Justices. In 1983, for example, 4222 new cases were filed, and that number rose to 6897 in 1993. See SuPREME COURT COMPENDIUM, supra note 43, at 62 tbl.2-2. During that period, no Justice voted to grant more than 275 cases in a Term, and the great majority voted to grant fewer than 150 .

69. THE SUPREME COURT COMPENDIUM provides the percentage of cases in which each Justice took the liberal position in different issue areas each Term. See id. at 490-523 tbl.6-3. We used each Justice's average score over the 1983-1993 terms in the civil liberties area, which includes the areas of criminal procedure, civil rights, First Amendment, due process, privacy, and attorney issue areas. The authors state that the term "liberal" is "most appropriate [in the civil liberties area], where it signifies pro-defendant votes in criminal procedure cases, pro-women or -minorities in civil rights cases, pro-individual against the government in First Amendment, due process, and privacy cases, and pro-attorney in attorneys' fees and bar membership cases." Id. at 523.

70. These appear to be the cut-off points that the authors of THE SUPREME COURT COMPENDIUM used, though they lumped all moderates together in one large category. See id. at 482.

71. See id. at $490-523$ tbl.6-3. 
concerns about whether they will win on the merits play a substantial role. $^{72}$ In general, the more conservative Justices had higher grant rates than the more liberal Justices, over a period when the Court's decisions on the merits tended in a conservative direction. ${ }^{73}$ But there were several exceptions to this general trend. Three conservative Justices-Chief Justice Burger, Justice Scalia, and Justice Kennedy (a moderateconservative) - ranked in the lower half of the full group. Indeed, Chief Justice Burger was among only four Justices who voted to grant fewer than $60 \%$ of the cases. Two of the moderate-liberal Justices-Justice Blackmun and Justice Ginsburg - were among the five Justices with grant rates over $70 \%$. (Our data on Justice Ginsburg, however, is only from her first Term on the Court, making it somewhat unreliable.) The Justices and their grant rates, ranked from high to low, are listed in Table 1 below. $^{74}$

Table 1: Grant Rates of Justices in All Cases Granted

\begin{tabular}{lcllc}
\hline Justice & Grant Rate & & Justice & Grant Rate \\
\cline { 1 - 2 } BRW & 89.9 & & LFP & 64.1 \\
SOC & 74.4 & AMK & 60.9 \\
RBG & 73.9 & AS & 60.8 \\
WHR & 70.3 & WB & 57.0 \\
CT & 70.2 & JPS & 53.5 \\
HAB & 70.1 & TM & 51.0 \\
DS & 64.9 & WJB & 50.8 \\
\hline
\end{tabular}

We have argued elsewhere that, while merits-oriented concerns play a significant role in the Justices' decisionmaking at the certiorari stage, the Justices' decisions on certiorari are based on a complex and multidimensional set of considerations that also include administrative,

72. This observation is consistent with the results reported in Caldeira et al., Sophisticated Voting, supra note 35, at 564-65 (finding that a conservative Justice's probability of voting for certiorari increases when the Court is conservative and that a liberal Justice's probability of voting for certiorari declines when the Court is conservative).

73. THE SUPREME COURT COMPENDIUM tracks the proportion of cases decided in a liberal direction for each Term. See SuPREME CourT COMPENDIUM, supra note 43, at 207-08, 231-35 tbl.3-8. In civil liberties cases, which include the areas of criminal procedure, civil rights, First Amendment, due process, privacy, and attorney issue areas, an average of $41.6 \%$ of cases were decided in a liberal direction from 1983 to 1993, the period of our sample. See id. at 233-34 tbl.3-8.

74. The Justices are indicated by their initials: Byron R. White (BRW); Sandra Day O'Connor (SOC); Ruth Bader Ginsburg (RBG); William H. Rehnquist (WHR); Clarence Thomas (CT); Harry A. Blackmun (HAB); David Souter (DS); Lewis F. Powell (LFP); Anthony M. Kennedy (AMK); Antonin Scalia (AS); Warren Burger (WB); John Paul Stevens (JPS); Thurgood Marshall (TM); and William J. Brennan (WJB). 
rule-based, and jurisprudential factors. ${ }^{75}$ The Justices' overall grant rates in cases granted reflect the composite influence of these distinct considerations.

In high-profile cases, however, the Justices' grant rates correlated much more closely with their ideological inclinations. Table 2, below, sets out the following data for each Justice: (1) grant rate in high-profile cases; (2) grant rate in low-profile cases; (3) the difference between these two grant rates; and (4) the percentage of civil liberties cases in which he or she voted in a liberal direction (with a label for which rough category he or she fell within).

Table 2: Grant Rates of Justices in High-Profile and Low-Profile Cases Ordered by Grant Rate in High-Profile Cases

\begin{tabular}{lllll}
\hline Justice & $\begin{array}{l}\text { High- } \\
\text { Profile } \\
\text { Rate }\end{array}$ & $\begin{array}{l}\text { Low-Profile } \\
\text { Rate }\end{array}$ & $\begin{array}{l}\text { Difference } \\
\text { (High }- \\
\text { Low) }\end{array}$ & $\begin{array}{l}\text { Liberal Voting in } \\
\text { Civil Liberties } \\
\text { Cases }\end{array}$ \\
\hline White & $87.4 \%$ & $90.1 \%$ & -2.7 & $34.6 \%(\mathrm{C})$ \\
O'Connor & $77.5 \%$ & $73.9 \%$ & 3.6 & $35.8 \%(\mathrm{M}-\mathrm{C})$ \\
Thomas & $76.6 \%$ & $69.5 \%$ & 7.1 & $26.6 \%(\mathrm{C})$ \\
Rehnquist & $76.2 \%$ & $69.2 \%$ & 7.0 & $22.9 \%(\mathrm{C})$ \\
Burger & $75.9 \%$ & $55.2 \%$ & 20.7 & $27.5 \%(\mathrm{C})$ \\
Ginsburg & $72.7 \%$ & $74.1 \%$ & -1.4 & $55.3 \%(\mathrm{M}-\mathrm{L})$ \\
Kennedy & $71.4 \%$ & $59.8 \%$ & 11.6 & $38.0 \%(\mathrm{M}-\mathrm{C})$ \\
Scalia & $68.0 \%$ & $59.5 \%$ & 8.5 & $30.1 \%(\mathrm{C})$ \\
Souter & $67.3 \%$ & $64.5 \%$ & 2.8 & $50.2 \%(\mathrm{M}-\mathrm{C})$ \\
Powell & $66.9 \%$ & $63.8 \%$ & 3.1 & $36.1 \%(\mathrm{M}-\mathrm{C})$ \\
Blackmun & $65.0 \%$ & $70.7 \%$ & -5.7 & $66.2 \%(\mathrm{M}-\mathrm{L})$ \\
Stevens & $54.9 \%$ & $53.4 \%$ & 1.5 & $66.9 \%(\mathrm{M}-\mathrm{L})$ \\
Brennan & $48.0 \%$ & $51.2 \%$ & -3.2 & $81.8 \%(\mathrm{~L})$ \\
Marshall & $45.9 \%$ & $51.6 \%$ & -5.7 & $83.3 \%(\mathrm{~L})$ \\
\hline
\end{tabular}

75. See generally Cordray \& Cordray, Philosophy of Certiorari, supra note 1, at 406-51 (discussing factors that influence decisionmaking at the certiorari stage); Cordray \& Cordray, Strategy in Case Selection, supra note 41, at 16-30 (discussing the evidence of non-merits-oriented factors in the Justices' voting behavior). 
With one exception, the conservative and moderate-conservative Justices had higher (and often considerably higher) grant rates in highprofile cases than the liberal and moderate-liberal Justices. The one exception was Justice Ginsburg, whose grant rate in such cases was slightly higher than that of other moderate-liberal Justices; but again, our data on her voting behavior is limited to her first Term.

Moreover, with the exception of Justice Ginsburg, all of the Justices whose grant rates were "out of order" in the group of all cases granted moved into their natural place in the group of high-profile cases. Chief Justice Burger, Justice Scalia, and Justice Kennedy rose out of the bottom tier, with Chief Justice Burger tallying the highest difference by voting to grant $20.7 \%$ more high-profile than low-profile cases, Justice Kennedy voting to grant $11.6 \%$ more and Justice Scalia voting to grant $8.5 \%$ more. At the other end of the ideological spectrum, Justice Blackmun moved down the ladder to join the other moderate-liberal Justices, voting to grant $5.7 \%$ fewer cases in the high-profile group.

On the other hand, for most of the Justices, the margin of difference in their high-profile and low-profile grant rates was not statistically significant. ${ }^{76}$ Indeed, the difference was statistically significant only for Chief Justice Burger and Justice Kennedy, whose grant rates rose dramatically in high-profile cases. For the rest, the results suggest that their approach to granting high-profile cases may be neither more strategic nor more institution-minded, but rather roughly comparable to their approach in low-profile cases. ${ }^{77}$

Nonetheless, the pattern that emerged from the data is hard to ignore: in this conservative period of the Court, virtually all of the conservative and moderate-conservative Justices voted to grant high-profile cases at a greater rate than low-profile cases, and virtually all of the liberal and

76. In the social sciences, a comparison is considered to be statistically significant if there is only a $5 \%$ chance that the difference in means observed could have occurred by chance alone. In calculating significance, the comparisons are dependent on the observed differences between the means in light of the number of observations. See EARL BABBIE, THE Practice OF Social RESEARCH 458 (6th ed. 1992) (discussing statistical significance); THOMAS H. WONNACOTT \& RONALD J. WONNACOTT, INTRODUCTORY STATISTICS 552 (5th ed. 1990) (same). In our study, the difference in Chief Justice Burger's grant rate in high-profile and low-profile cases was statistically significant at the conventional 5\% level, the difference in Justice Kennedy's was statistically significant at the $10 \%$ level, and the differences for all the other Justices were not statistically significant. (There was insufficient data to evaluate Justice Ginsburg's results.)

77. It is also possible that there are non-strategic reasons that motivate conservative Justices to a greater extent than liberal Justices to vote to grant cases that just happen to be high-profile in nature. For example, conservative Justices may be more inclined to feel that the lower courts have been too "activist" in cases presenting questions that properly belong to the political branchescases which would tend to be high-profile - and thus vote more frequently to grant for that nonstrategic reason. 
moderate-liberal Justices voted to grant high-profile cases at a lower rate than low-profile cases. ${ }^{78}$ This pattern, combined with the overall higher grant rates of the conservative and moderate-conservative Justices, at least suggests that the Justices' willingness to vote to grant high-profile cases is linked to their likelihood of winning those cases on the merits, which in turn suggests that the Justices behave more strategically in high-profile cases.

\section{B. Degree of Unanimity in Voting at the Certiorari Stage}

We also considered the Justices' level of agreement in granting highprofile cases as opposed to low-profile cases. To do this, we calculated the percentage of cases that were granted with each possible vote total (from nine votes to four votes) for each of the 1983-1993 Terms. ${ }^{79}$ We then compared the percentage of cases granted with each vote total for low-profile versus high-profile cases.

Although there was a fair degree of variation among the Terms, the most striking result was the nearly uniform decline in high-profile cases granted with a bare four votes. In nine of the eleven Terms in our dataset, the Justices granted a smaller percentage of high-profile cases with only four votes than they did low-profile cases. ${ }^{80}$ Overall, the percentage of high-profile cases granted with the minimum four votes was $10 \%$ lower than that of low-profile cases. As Tables 3 and 4 indicate, in our 1983-1993 sample an average of 31\% of the low-profile cases were granted with the minimum four votes, whereas an average of $21 \%$ of high-profile cases were granted with the minimum four votes. ${ }^{81}$

78. Only two Justices broke the pattern. The conservative Justice White voted to grant a slightly lower percentage of high-profile cases, but given his unusually high grant rate $(90 \%$ in all cases granted), his modest drop in voting for high-profile cases could actually reflect a strategic preference not to grant cases that the liberals were likely to win. In addition, the moderate-liberal Justice Stevens's grant rate moved up slightly in high-profile cases.

79. On certiorari, four votes are sufficient for the Court to grant a case for full review on the merits. See Revesz \& Karlan, supra note 13, at 1069-70 (describing the origins of the "Rule of Four"). In one high-profile case, R.A.V. v. City of St. Paul, 505 U.S. 377 (1992), we were only able to track down three votes to grant from the available docket books. We did not include this case in our comparison.

80. In calculating the average percentages, we averaged the per-Term percentages over the eleven Terms.

81. This difference is statistically significant at the conventional 5\% level. See supra note 76 (discussing statistical significance). 
Table 3: Average Percentage of Votes to Grant in High-Profile Cases

\begin{tabular}{llllllll}
\hline Term & \# Cases & 4 Votes & $\mathbf{5}$ Votes & 6 Votes & 7 Votes & $\mathbf{8}$ Votes & 9 Votes \\
\hline 1993 & 11 & $18 \%$ & $9 \%$ & $9 \%$ & $9 \%$ & $9 \%$ & $45 \%$ \\
1992 & 17 & $35 \%$ & $12 \%$ & $0 \%$ & $12 \%$ & $6 \%$ & $35 \%$ \\
1991 & 10 & $0 \%$ & $40 \%$ & $40 \%$ & $10 \%$ & $0 \%$ & $10 \%$ \\
1990 & 16 & $19 \%$ & $13 \%$ & $25 \%$ & $19 \%$ & $6 \%$ & $13 \%$ \\
1989 & 13 & $23 \%$ & $23 \%$ & $15 \%$ & $15 \%$ & $8 \%$ & $15 \%$ \\
1988 & 20 & $15 \%$ & $30 \%$ & $20 \%$ & $0 \%$ & $20 \%$ & $15 \%$ \\
1987 & 18 & $17 \%$ & $22 \%$ & $6 \%$ & $11 \%$ & $28 \%$ & $17 \%$ \\
1986 & 11 & $27 \%$ & $36 \%$ & $18 \%$ & $0 \%$ & $18 \%$ & $0 \%$ \\
1985 & 18 & $50 \%$ & $22 \%$ & $0 \%$ & $11 \%$ & $6 \%$ & $11 \%$ \\
1984 & 13 & $15 \%$ & $62 \%$ & $8 \%$ & $0 \%$ & $15 \%$ & $0 \%$ \\
1983 & 14 & $14 \%$ & $36 \%$ & $7 \%$ & $7 \%$ & $29 \%$ & $7 \%$ \\
Average & & $21 \%$ & $28 \%$ & $13 \%$ & $9 \%$ & $13 \%$ & $15 \%$ \\
\hline
\end{tabular}

Table 4: Average Percentage of Votes to Grant in Low-Profile Cases

\begin{tabular}{llllllll}
\hline Term & \# Cases & $\mathbf{4}$ Votes & $\mathbf{5}$ Votes & $\mathbf{6}$ Votes & $\mathbf{7}$ Votes & $\mathbf{8}$ Votes & $\mathbf{9}$ Votes \\
\hline 1993 & 81 & $27 \%$ & $14 \%$ & $11 \%$ & $11 \%$ & $12 \%$ & $25 \%$ \\
1992 & 82 & $20 \%$ & $18 \%$ & $12 \%$ & $17 \%$ & $12 \%$ & $21 \%$ \\
1991 & 101 & $33 \%$ & $16 \%$ & $14 \%$ & $10 \%$ & $13 \%$ & $15 \%$ \\
1990 & 112 & $29 \%$ & $21 \%$ & $10 \%$ & $15 \%$ & $11 \%$ & $13 \%$ \\
1989 & 107 & $36 \%$ & $18 \%$ & $16 \%$ & $15 \%$ & $6 \%$ & $9 \%$ \\
1988 & 117 & $32 \%$ & $15 \%$ & $16 \%$ & $11 \%$ & $16 \%$ & $10 \%$ \\
1987 & 138 & $38 \%$ & $18 \%$ & $21 \%$ & $9 \%$ & $8 \%$ & $5 \%$ \\
1986 & 145 & $30 \%$ & $24 \%$ & $18 \%$ & $10 \%$ & $12 \%$ & $7 \%$ \\
1985 & 157 & $33 \%$ & $13 \%$ & $19 \%$ & $12 \%$ & $11 \%$ & $11 \%$ \\
1984 & 162 & $38 \%$ & $22 \%$ & $21 \%$ & $9 \%$ & $7 \%$ & $4 \%$ \\
1983 & 123 & $26 \%$ & $22 \%$ & $21 \%$ & $15 \%$ & $10 \%$ & $7 \%$ \\
Average & & $31 \%$ & $18 \%$ & $16 \%$ & $12 \%$ & $11 \%$ & $12 \%$ \\
\hline
\end{tabular}


Because it takes five votes to win on the merits, this marked decline in cases granted with a four-vote minority suggests that the Justices are thinking more strategically about whether they will ultimately win on the merits when they are deciding whether to grant high-profile cases. Indeed, in a number of high-profile cases where certiorari was granted with a bare minority of four votes, three or even all four of the Justices voting to grant ended up losing on the merits. Results such as these-in key constitutional cases such as Board of Education of Kiryas Joel Village School District v. Grumet, ${ }^{82}$ TXO Production Corp. v. Alliance Resources Corp. ${ }^{83}$ McCleskey v. Kemp,${ }^{84}$ Grand Rapids School District v. Ball, ${ }^{85}$ and Thornburgh v. American College of Obstetricians and Gynecologists ${ }^{86}$ - would tend to serve as reminders of the risk involved in voting to grant an important case based on the assumption that somehow a crucial fifth vote would materialize later on the merits. At other times, of course, the Justices voting as a minority to grant did succeed in picking up enough votes to win on the merits, ${ }^{87}$ but that prospect was at least a somewhat hazardous one.

Interestingly, the percentage of cases granted with five votes (enough to form a majority on the merits) went up in eight of the eleven Terms in our dataset, and overall the percentage of high-profile cases granted with five votes was $10 \%$ higher than in low-profile cases. ${ }^{88}$ In contrast to

82. 512 U.S. 687 (1994) (constitutionality of providing special education services to children in parochial schools under the Establishment Clause; Chief Justice Rehnquist and Justices Scalia and Thomas voted to grant and ended up in dissent while Justice Kennedy voted to grant and ended up concurring in the judgment).

83. 509 U.S. 443 (1993) (constitutionality of punitive damages award under the Due Process Clause; Justices White, O'Connor, and Souter voted to grant and ended up in dissent while Justice Blackmun voted to grant and ended up joining the plurality opinion).

84. 481 U.S. 279 (1987) (constitutionality of Georgia's capital punishment system under the Eighth Amendment and Equal Protection Clause; Justices Brennan, Marshall, Blackmun, and Stevens voted to grant and ended up in dissent).

85. 473 U.S. 373 (1985) (constitutionality of classes provided primarily to parochial school children at public expense under the Establishment Clause; Chief Justice Burger and Justices White, Rehnquist, and O'Connor voted to grant and ended up in partial or full dissent), overruled by Agostini v. Felton, 521 U.S. 203 (1997).

86. 476 U.S. 747 (1986) (constitutionality of informed consent law for abortions under the Due Process Clause; Chief Justice Burger and Justices White, Rehnquist, and O'Connor voted to grant and ended up in dissent), overruled by Planned Parenthood of Se. Pa. v. Casey, 505 U.S. 833 (1992).

87. See, e.g., Bray v. Alexandria Women's Health Clinic, 506 U.S. 263 (1993) (applicability of federal civil rights laws to persons obstructing access to abortion clinics; four grant votes led to a majority opinion with a concurrence); Booth v. Maryland, 482 U.S. 496 (1987) (constitutionality of victim impact statement in capital murder trial under the Eighth Amendment; four grant votes led to a majority opinion), overruled by Payne v. Tennessee, 501 U.S. 808 (1991); Local 28 of the Sheet Metal Workers' Int'l Ass'n v. EEOC, 478 U.S. 421 (1986) (scope of coverage for racial discrimination under Title VII; four grant votes led to a majority opinion with a concurrence).

88. Id. In our 1983-1993 sample, an average of $18 \%$ of the low-profile cases were granted with five votes, whereas an average of $28 \%$ of high-profile cases were granted with five votes. See 
cases where the four Justices voting to grant ultimately lost on the merits are cases where the same five Justices who voted to grant won an ultimate 5-4 victory on the merits, such as Dolan v. City of Tigard, ${ }^{89}$ Spallone v. United States, ${ }^{90}$ and Wards Cove Packing Co. v. Atonio. ${ }^{91}$ And, as would be expected, in other cases their five grant votes sometimes served as the foundation for much broader victories on the merits. $^{92}$

Even so, the Justices still granted a significant percentage of highprofile cases with a minority of votes $-21 \%$ in our dataset. Since granting a highly controversial case with only four votes means that the granting Justices do not start with a majority, this behavior seems nonstrategic at first blush. In each of these cases, the Justices who voted to grant may well have done so because they believed that it was the Court's institutional responsibility to hear the case, regardless of whether the ultimate outcome would coincide with their ideological preferences. It is, however, entirely possible that the four Justices' willingness to grant stemmed not from their sense of institutional responsibility, but rather from their hope or expectation that they would be able to pull in a fifth Justice on the merits. In some cases, Justices might be willing to take greater risks in this way to "move" precedent, which cannot be achieved by denials of certiorari alone. ${ }^{93}$

supra tbls. 3 \& 4. This difference is statistically significant at the $10 \%$ level. See supra note 76 (discussing statistical significance).

89. 512 U.S. 374 (1994) (constitutionality of city's requirement that landowner dedicate private land for a public greenway under the Takings Clause; Chief Justice Rehnquist, along with Justices O'Connor, Scalia, Kennedy, and Thomas voted to grant and constituted the majority on the merits).

90. 493 U.S. 265 (1990) (determination of whether federal judicial remedial powers authorize contempt sanctions imposing fines directly against city councilmembers; Chief Justice Rehnquist, along with Justices White, O'Connor, Scalia, and Kennedy voted to grant and constituted the majority on the merits).

91. 490 U.S. 642 (1989) (determination of when the evidence will support a disparate impact claim for racial discrimination under Title VII; Chief Justice Rehnquist, along with Justices White, O'Connor, Scalia, and Kennedy voted to grant and constituted the majority on the merits), superseded by statute, Civil Rights Act of 1991, Pub. L. No. 102-166, 105 Stat. 1074, as recognized in Raytheon Co. v. Hernandez, 540 U.S. 44 (2003).

92. See, e.g., Lamb's Chapel v. Ctr. Moriches Union Free Sch. Dist., 508 U.S. 384 (1993) (constitutionality of denying a church access to school premises open to other groups under the Free Speech Clause; five grant votes led to unanimous result with two concurrences); Hustler Magazine v. Falwell, 485 U.S. 46 (1988) (application of more restrictive First Amendment standards to tort of emotional distress; five grant votes led to unanimous result with one concurrence); Western Air Lines, Inc. v. Criswell, 472 U.S. 400 (1985) (scope of coverage for age discrimination under the ADEA; five grant votes led to unanimous decision on the merits).

93. One account of the Warren Court describes such a situation, in which Justice Brennan urged Chief Justice Warren to take a particular case to try to extend to the states the doctrine of Jencks v. United States, 353 U.S. 657 (1957), which required the prosecution to turn over witness statements to the defense:

'I suppose there would be a vehement protest,' Brennan wrote, 'and the probabilities are 
Overall, the Justices granted high-profile cases with higher vote totals than they did low-profile cases. In addition to granting a much higher percentage of high-profile cases with five votes instead of four, the Justices acted with substantial unanimity (casting eight or nine votes) in a somewhat greater percentage of high-profile cases than low-profile cases. $^{94}$ This increase at the upper end suggests that the Justices are indeed motivated, to some extent, by a sense of institutional responsibility to hear certain high-profile cases whose importance is indisputable. Over one-quarter of the cases in the high-profile category (and 5\% more cases than in the low-profile category) were granted with substantial unanimity, despite the fact that the Court tends to be more closely divided in such cases on the merits. ${ }^{95}$ Many of these "consensus" grants-including, for example, such textbook cases as Wisconsin $v$. Mitchell, ${ }^{96}$ Chisom v. Roemer ${ }^{97}$ Metro Broadcasting, Inc. v. FCC, ${ }^{98}$ Skinner v. Railway Labor Executives' Ass' $n,{ }^{99}$ and Mistretta v. United States ${ }^{100}$-address fundamental constitutional issues of undeniable importance.

As we discuss in more detail below, the Justices do vote to grant high-profile cases that they ultimately lose on the merits, and indeed, they lose more frequently on the merits in high-profile cases that they

we would lose out on the merits. The latter probability may be good reason to pass up this opportunity, but I do think we'll wait a long time before we get a question as sharply presented.' Warren persuaded Brennan to pass up the case. But other opportunities would soon come along. The chief and the 'deputy chief' vowed to watch for them. Then, they believed, they would make history.

EISLER, supra note 26, at 165.

94. In our 1983-1993 sample, an average of $11 \%$ of the low-profile cases were granted with eight votes and $12 \%$ were granted with nine votes, whereas an average of $13 \%$ of the high-profile cases were granted with eight votes and $15 \%$ were granted with nine votes. See supra tbls. 3 \& 4 . These differences, however, were not statistically significant. See supra note 76 (discussing statistical significance).

95. We tracked the Justices' votes from certiorari through the merits in five Terms (1993, 1992, 1991, 1988, and 1984). See infra Part III.D (discussing our selection of the sample Terms). In our sample Terms, the average size of the majority on the merits was seven Justices in low-profile cases, whereas it was only six Justices in high-profile cases, reflecting the predictably deeper and more persistent ideological divides among the Justices in deciding the merits of "hot-button" issues.

96. 508 U.S. 476 (1993) (constitutionality of hate crime laws under the First Amendment).

97. 501 U.S. 380 (1991) (applicability of Voting Rights Act claim for diluting minority voting strength to judicial elections).

98. 497 U.S. 547 (1990) (constitutionality of affirmative action policies for minority preference and broadcast diversity under the Equal Protection Clause), overruled by Adarand Constructors, Inc. v. Pena, 515 U.S. 200 (1995).

99. 489 U.S. 602 (1989) (constitutionality of employee drug testing under the Fourth Amendment, heard together with National Treasury Employees Union v. Von Raab, 489 U.S. 656 (1989), which was also granted unanimously).

100. 488 U.S. 361 (1989) (constitutionality of federal sentencing guidelines under the separation of powers doctrine). 
voted to grant than they do in low-profile cases that they voted to grant. This data, combined with the higher percentage of high-profile cases granted with substantial unanimity, suggests that institutional considerations are driving the Justices' decisionmaking at least to some extent.

Nonetheless, we think that the more natural interpretation of the downward plunge in high-profile cases granted with a minority of votes is that Justices are more concerned about granting such cases without a dependable majority with which to prevail at the merits stage. Although there was a modest rise in the percentage of high-profile cases granted with substantial unanimity, it was not statistically significant, and it was coupled with a corresponding drop in cases granted with six or seven votes. $^{101}$ Thus, while institutional considerations likely play a role in the Justices' decisions to vote to grant some of the most obviously important high-profile cases, it seems that such considerations do not fully account for the much larger shift away from cases granted with a minority of votes. Instead, strategic concerns are the more likely explanation for the much smaller percentage of high-profile cases granted with a mere four votes (and corresponding increase in high-profile cases granted with five votes).

\section{Voting Patterns Among Ideologically Aligned and Ideologically Opposed Justices}

To gauge further whether the Justices act more strategically in highprofile cases, we considered whether Justices who are ideologically aligned on the merits tend to vote together more frequently on certiorari in high-profile cases than they vote together on certiorari in the full set of cases granted. We also considered the converse: whether Justices who are ideologically opposed on the merits tend to vote together less frequently on certiorari in high-profile cases than they vote together on certiorari in the full set of cases granted.

In a recent Article, we looked more generally at whether Justices who are aligned on the merits also tend to vote together at the certiorari stage, and whether Justices who are opposed on the merits also tend to

101. In our 1983-1993 sample, an average of $16 \%$ of the low-profile cases were granted with six votes and $12 \%$ were granted with seven votes, whereas an average of $13 \%$ of the high-profile cases were granted with six votes and $9 \%$ were granted with seven votes. See supra tbls. 3 \& 4 . The difference in low-profile versus high-profile cases granted with six votes was not statistically significant, but it was statistically significant at the $10 \%$ level for cases granted with seven votes. See supra note 76 (discussing statistical significance). 
disagree at the certiorari stage. ${ }^{102}$ To do that analysis, we used the Harvard Law Review's annual statistical recaps to assess how ideologically in sync the Justices are. The statistical recaps, which provide information on voting alignments in merits cases, report how frequently each pair of Justices agreed in cases decided on the merits. ${ }^{103}$ They thus provide a good measure of the Justices' ideological compatibility as a general matter.

We then compiled comparable voting alignment information at the certiorari stage for each pair of Justices, using data on the Justices' case selection votes for the 1983 through the 1993 Terms that we gathered from the docket books of Justices Blackmun, Brennan, and Marshall. ${ }^{104}$ In compiling the certiorari voting alignment information, we included in our dataset the Justices' case selection votes in all cases granted for plenary review on the merits, in order to make the most direct comparison of the Justices' voting behavior at the case selection stage versus the merits stage. ${ }^{105}$

102. See Cordray \& Cordray, Strategy in Case Selection, supra note 41, at 1-3, 16-30.

103. The Harvard Law Review treats two Justices as having voted together "whenever they join in the same opinion, as indicated either by the reporter or by the explicit statement of a Justice in the body of his own opinion." The Supreme Court, 1967 Term, 82 HARV. L. REV. 93, 307 n.f (1968). It calculates the percentage of agreement by dividing the number of times that one Justice voted with another in opinions of the Court, opinions announcing the judgment of the Court, concurrences, and dissents by the number of cases in which both Justices participated. See id.; see also id. at 301-02 (describing more fully how it calculates the statistics).

104. We treated all "Join-3" votes as votes to grant. See supra note 67 (describing the Join-3 vote and its functional equivalence to a vote to grant).

105. We restricted our dataset to cases that were granted, because so many of the certiorari petitions filed are frivolous. Since the vast majority of petitions are unanimously denied, using the full set of petitions filed would obscure the real differences in voting behavior among the Justices in nonfrivolous cases. Alternatively, we could have attempted to include in our dataset all cases in which a nonfrivolous petition was filed by, for example, including all cases that received at least one vote to grant. We did not use this approach for two reasons. First, limiting the dataset to cases that were granted makes the comparison between agreement on certiorari and agreement on the merits more direct because the two datasets contain approximately the same cases. We caution, however, that the comparison is not exact. This is primarily because we compared the Justices' voting behavior in the Term during which they cast the votes, whether on certiorari or on the merits. Many of the cases granted in one Term are not decided on the merits until a later Term, so the group of cases voted on at the certiorari stage will not mirror the group of cases voted on at the merits stage in any given Term. A related problem occurs when a Justice joins or leaves the Court, because he or she will have cast some votes at one stage but not the other. Also, we included in our certiorari dataset all cases that were granted, so that dataset contains some cases that were dismissed before the Court issued an opinion on the merits. Nonetheless, the overall comparison is quite close, especially since we averaged the voting alignments data over the Terms that each pair of Justices sat together.

The second reason we opted against using the larger group of nonfrivolous cases is that it allows the unusual voting behavior of one Justice to create a false sense of agreement among the other eight Justices. See also supra note 68 (discussing method of calculating grant rates). For example, Justice White voted to grant approximately 100 more cases per Term than any other Justice. Including all of those cases would significantly, but somewhat misleadingly, increase the rate of agreement among the eight other Justices. We recognize, however, that there are downsides to restricting the data pool 
We found that Justices who are ideologically aligned on the merits tend to vote together on certiorari much more frequently than those Justices who are ideologically opposed on the merits, indicating that there is a strong ideological or strategic element to the Justices' decisionmaking on certiorari. ${ }^{106}$ But we also found that the rate of agreement between almost all Justices was significantly lower on certiorari than on the merits, suggesting that other factors also play an important role in the Justices' case selection decisions. ${ }^{107}$

For this Article, we used the same data and methodology, but we segregated the high-profile cases in order to assess whether the Justices behave differently in such cases. We found that the Justices who were most closely aligned on the merits not only tended to vote together on certiorari, they also tended to vote together even more frequently on certiorari in high-profile cases. Over the eleven Terms we studied, there were seventy-six pairs of Justices, of which twenty-three had a merits agreement rate over $75 \%$. Of these ideologically-aligned pairs, twentyone (all but two) had a higher agreement rate on certiorari in high-profile cases than they did in the group of all cases granted. ${ }^{108}$ Moreover, the extent of the increase in the rate of agreement in high-profile cases was also more pronounced for these closely aligned pairings. While the average increase in the rate of agreement was $2.2 \%$ for the entire set of seventy-six pairings, the average increase in the rate of agreement was $5.9 \%$ for the closely-aligned Justices (i.e., those with a merits agreement rate of over $75 \%)^{109}$

The results were similar at the other end of the spectrum. Nineteen pairs agreed on the merits less than $55 \%$ of the time. Of these ideologically-opposed pairs, twelve (all but seven) had a lower

to cases granted. See Caldeira et al., Sophisticated Voting, supra note 35, at 552 (discussing problems of limiting dataset to cases granted). In particular, it is harder to identify certain kinds of strategic behavior, such as successful defensive denials, as well as certain kinds of non-strategic behavior. Justice White, for instance, felt strongly that the Court should hear cases presenting conflicts among the lower courts, and he voted to grant a large number of cases for that purpose. See, e.g., Beaulieu v. United States, 497 U.S. 1038, 1040 (1990) (mem.) (White, J., dissenting from denial of certiorari) ("[I]t is plain enough to me that quite a number of the cases involving conflicts have been denied review but could have been granted without presenting any danger of not being current in our docket.")

106. See Cordray \& Cordray, Strategy in Case Selection, supra note 41, at 20-21.

107. See id. at 21-23.

108. See Appendix B (setting out the pairings of Justices ranked ordinally by their agreement rate on the merits, averaged over the eleven Terms; their agreement rate and ordinal ranking on certiorari for all cases granted; and their agreement rate and ordinal ranking on certiorari for highprofile cases).

109. See id. We computed the average change in agreement rate by subtracting each pair of Justices' agreement rate on certiorari in all cases granted from their agreement rate in high-profile cases. We then averaged the results for all pairs. 
agreement rate on certiorari in high-profile cases than they did in the group of all cases granted. ${ }^{110}$ Even more strikingly, all eight of the pairs that agreed on the merits less than $50 \%$ of the time agreed even less frequently on certiorari in high-profile cases than they did in all cases granted. ${ }^{111}$ Not surprisingly, the average change in agreement rate for these ideologically-opposed Justices differed from the norm as well: while on average the full set of Justices voted together $2.2 \%$ more frequently on certiorari in high-profile cases than in all cases granted, the group of Justices with a merits agreement rate of less than $55 \%$ voted together $1.7 \%$ less frequently in high-profile cases than in all cases granted, and the group of Justices with a merits agreement rate of less than $50 \%$ voted together $5 \%$ less frequently in high-profile cases. ${ }^{112}$

These results indicate that ideological and strategic concerns about how the Court will ultimately decide a case on the merits play an even greater role in the Justices' certiorari decisions about whether to grant high-profile cases. While the overall increase in agreement rate in highprofile cases suggests that institutional concerns may hold some sway with the Justices in a certain number of these cases, the size of the increase was quite modest. On the whole, then, this data lends support for the view that the Justices tend to act more strategically in high-profile cases.

\section{Voting Behavior on the Merits in Cases the Justices Voted to Grant}

To explore further whether the Justices act more strategically in high-profile cases, we tracked each Justice's voting behavior from certiorari through the merits for five Terms: 1993, 1992, 1991, 1988, and 1984. In selecting the five Terms sampled, we chose the three most recent Terms for which certiorari voting data was available and two Terms from the 1980s (we used 1988 and 1984 because the Court had no changes in personnel during either of those Terms or in the Terms immediately succeeding them, when many of the cases granted were decided on the merits).

We analyzed the data in two ways. First, we looked at how frequently a Justice's vote to grant certiorari was followed by a vote to reverse on the merits. Second, we looked at how frequently a Justice's vote to grant certiorari was followed by a win on the merits. ${ }^{113}$

110. See id.

111. See id.

112. See id.

113. We are indebted to Banks Miller, who performed the statistical analysis on our data in this 


\section{Vote to Grant Followed by a Vote to Reverse on the Merits}

In the political science literature, tracking the frequency with which a Justice votes to grant certiorari and then votes to reverse on the merits is a relatively standard measure of the extent to which the Justices' certiorari decisions are motivated by their own ideological inclinations. ${ }^{114}$ In general, this approach assumes that a Justice is more likely to vote to grant a case when the lower court result conflicts with his or her own ideological preferences. ${ }^{115}$ Although this method fails to distinguish between cases in which a Justice's inclination for error correction is fundamentally ideological and those in which it is based on non-ideological legal considerations, ${ }^{116}$ it does provide some measure of ideology's role in the decisionmaking calculus.

With this measure, we considered the rate at which Justices voted to grant and then voted to reverse on the merits in low-profile cases as compared to the rate at which they did so in high-profile cases. ${ }^{117}$ Overall, there was no difference between the two categories: Justices who voted to grant and then voted to reverse did so in $62.9 \%$ of lowprofile cases and in $63.3 \%$ of high-profile cases. Table 5, below, displays the individual percentages.

Table 5: Percentage of Cases in Which Justices Voted to Grant and Then to Reverse on the Merits

\begin{tabular}{lll}
\hline Justice & High-Profile & Low-Profile \\
\hline Overall & $63.3 \%$ & $62.9 \%$ \\
Burger & $80.0 \%$ & $70.0 \%$ \\
Brennan & $63.6 \%$ & $60.4 \%$ \\
\hline
\end{tabular}

section.

114. For studies employing this method, see supra note 32 and accompanying text (discussing the political science literature).

115. For studies finding that a preference for reversal contains a strong ideological component, see supra note 33 and accompanying text (discussing the political science literature).

116. In areas such as tax, bankruptcy, or patent law, for example, it seems likely that purely legal considerations, rather than ideological considerations, will predominate. See also Caldeira et al., Sophisticated Voting, supra note 35, at 552-53 (discussing other limitations of this method).

117. At the certiorari stage, we included all votes to grant, note jurisdiction, postpone decision on jurisdiction, and Join-3 as votes to grant. See supra note 67 (discussing Join-3 votes). At the merits stage, we treated Justices as voting to reverse in all cases where (1) they joined the majority, concurred, or concurred in the judgment in a case that was reversed, reversed in part and affirmed in part, or vacated and remanded; or (2) they dissented, concurred in part and dissented in part, or concurred in the judgment in part and dissented in part in a case that was affirmed or affirmed in part (as long as nothing was reversed). 
Table 5 (continued)

\begin{tabular}{lll}
\hline Justice & High-Profile & Low-Profile \\
\hline White & $63.0 \%$ & $63.8 \%$ \\
Marshall & $69.2 \%$ & $55.9 \%$ \\
Blackmun & $61.9 \%$ & $60.6 \%$ \\
Powell & $66.7 \%$ & $65.1 \%$ \\
Rehnquist & $67.9 \%$ & $65.3 \%$ \\
Stevens & $62.8 \%$ & $71.4 \%$ \\
O'Connor & $69.4 \%$ & $60.5 \%$ \\
Scalia & $52.4 \%$ & $61.4 \%$ \\
Kennedy & $59.5 \%$ & $59.3 \%$ \\
Souter & $64.3 \%$ & $66.0 \%$ \\
Thomas & $57.1 \%$ & $58.4 \%$ \\
Ginsburg & $62.5 \%$ & $63.6 \%$ \\
\hline
\end{tabular}

The most obvious explanation for this result is, of course, that the Justices approach high-profile cases in the same way that they do lowprofile cases, meaning that they generally (but certainly not always) vote to grant cases that they want to reverse on the merits. Another possibility, however, is that in high-profile cases the Justices do act more strategically, but the evidence of such behavior is obscured in the voting data. This might occur if the Justices are also aggressively granting more cases that they wish to affirm. ${ }^{118}$ A Justice's keen interest in a highprofile issue might lead the Justice not only to vote to grant cases that he or she believes were wrongly decided below, but also to vote to grant cases that were rightly decided below, if they are likely to be affirmed on the merits (and thus become the law of the land). In other words, a Justice's voting behavior might be highly strategic in high-profile cases, in the sense that the Justice is voting to grant based on whether he or she will likely win on the merits, regardless of whether the Justice thinks that the result below should be reversed or affirmed.

118. An "aggressive grant" occurs when a Justice votes to grant a case in order to affirm and thus give broader effect to a desirable result below by extending its precedential effect nationwide. See, e.g., EPSTEIN \& KNIGHT, supra note 36, at 80 (describing aggressive grants). 
Although studies suggest that the Justices are much more hesitant to vote to grant cases that they wish to affirm because they have more to lose, ${ }^{119}$ high-profile cases present a different calculus of costs and benefits. In high-profile cases, the Justices may perceive themselves as having more at stake, but they may also have a better sense of how most of their colleagues will vote and a greater desire to see their preferred outcome achieved at the Supreme Court level in order to set a binding precedent throughout the country. For these reasons, it seems plausible that at least the Justices who expect to be in the majority are more frequently reaching out to grant high-profile cases that they wish to affirm. ${ }^{120}$

The data, however, does not appear to support this hypothesis. As noted above, the rate at which the Justices collectively voted to grant and then voted to affirm on the merits in low-profile versus high-profile cases was the same: overall, Justices who voted to grant and then voted to affirm did so in $37.1 \%$ of low-profile cases and in $36.7 \%$ of high-profile cases. Even more telling, although there was some variation in the rates at which the individual Justices voted to reverse in high-profile versus low-profile cases, none of those variations were statistically significant. $^{121}$ During this conservative period of the Court, one would expect to see the more conservative Justices reaching out more aggressively to grant and affirm in high-profile cases, yet there were no differences among any of the Justices, let alone blocs of Justices. Moreover, in the larger set of all cases granted (regardless of whether the Justice had voted to grant or deny at the certiorari stage), there was virtually no difference in the rate at which Justices voted to affirm in high-profile versus low-profile cases: overall, Justices voted to affirm in $42 \%$ of the low-profile cases and in $43 \%$ of the high-profile cases. And again, although there was some variation in the rates of the individual Justices, none of those variations were statistically significant. ${ }^{122}$ Table 6 sets out the affirmance rates for each Justice.

119. See supra note 35 (citing studies).

120. Likewise, in these high-stakes cases Justices may be more careful to vote for a "good vehicle," and a case decided in the Justice's preferred direction below may present better facts.

121. The differences in the rates at which the individual Justices voted to grant and then voted to reverse in high-profile versus low-profile cases were not statistically significant for any Justice at the conventional $5 \%$ level, and were statistically significant for only one Justice (Justice O'Connor) at the $10 \%$ level. See supra note 76 (discussing statistical significance).

122. See supra note 76 (discussing statistical significance). In our study, the differences in the rates at which the individual Justices voted to affirm in high-profile versus low-profile cases were not statistically significant for any Justice at the conventional $5 \%$ level or at the more generous $10 \%$ level. 
Table 6: Percentage of All Cases in Which Justice Voted to Affirm on the Merits Regardless of Whether Justice Voted to Grant or Deny Certiorari

\begin{tabular}{lll}
\hline Justice & High-Profile & Low-Profile \\
\hline Overall & $43.0 \%$ & $42.2 \%$ \\
Burger & $30.8 \%$ & $36.4 \%$ \\
Brennan & $60.6 \%$ & $49.8 \%$ \\
White & $38.5 \%$ & $35.1 \%$ \\
Marshall & $60.6 \%$ & $54.9 \%$ \\
Blackmun & $46.9 \%$ & $43.9 \%$ \\
Powell & $41.7 \%$ & $44.4 \%$ \\
Rehnquist & $42.3 \%$ & $40.6 \%$ \\
Stevens & $46.5 \%$ & $44.6 \%$ \\
O'Connor & $35.2 \%$ & $38.0 \%$ \\
Scalia & $44.8 \%$ & $43.1 \%$ \\
Kennedy & $36.2 \%$ & $40.5 \%$ \\
Souter & $36.8 \%$ & $35.9 \%$ \\
Thomas & $39.5 \%$ & $46.4 \%$ \\
Ginsburg & $45.5 \%$ & $40.3 \%$ \\
\hline
\end{tabular}

The more conventional explanation thus appears to be the more likely one: with respect to voting to grant cases that they want to reverse on the merits, the Justices approach high-profile cases at the certiorari stage in very much the same way that they do low-profile cases.

2. Vote to Grant Followed by a Win on the Merits

Because the Court and the Justices have so much at stake in highprofile cases, the frequency with which the Justices vote to grant certiorari and then win on the merits may be a better indicator of whether the Justices behave more strategically in high-profile cases. And conversely, the frequency with which a Justice votes to grant and then loses on the merits may tell us something about the Justice's willingness to take a case because he or she believes that it is the Court's institutional responsibility to do so. 
Therefore, we also analyzed the voting data in our five-Term sample by tracking how frequently a Justice's vote to grant certiorari was followed by a win on the merits. ${ }^{123}$ The results were surprising. As Table 7 shows, every Justice but one had a lower winning percentage in high-profile cases than in low-profile cases, and for most, the difference was statistically significant. ${ }^{124}$ On average, there was an $11 \%$ drop in the Justices' winning percentage from low-profile cases to high-profile cases: Justices who voted to grant low-profile cases won $82.6 \%$ of those cases on the merits, whereas Justices who voted to grant high-profile cases won only $71.6 \%$ of those cases on the merits.

Table 7: Percentage of Cases Where Justice Voted to Grant and Won on the Merits

\begin{tabular}{llll}
\hline Justice & High-Profile & Low-Profile & $\begin{array}{l}\text { Significance } \\
\text { (p-value) }\end{array}$ \\
\hline Overall & $71.6 \%$ & $82.6 \%$ & 0.000 \\
Burger & $70.0 \%$ & $90.0 \%$ & 0.038 \\
Brennan & $45.5 \%$ & $72.9 \%$ & 0.028 \\
White & $76.1 \%$ & $88.9 \%$ & 0.007 \\
Marshall & $46.2 \%$ & $68.5 \%$ & 0.055 \\
Blackmun & $64.3 \%$ & $72.6 \%$ & 0.133 \\
Powell & $100 \%$ & $88.4 \%$ & 0.870 \\
Rehnquist & $73.6 \%$ & $87.6 \%$ & 0.003 \\
Stevens & $53.5 \%$ & $70.6 \%$ & 0.012 \\
O'Connor & $77.9 \%$ & $85.1 \%$ & 0.082 \\
Scalia & $74.4 \%$ & $86.2 \%$ & 0.027 \\
Kennedy & $87.8 \%$ & $93.5 \%$ & 0.101 \\
Souter & $82.1 \%$ & $83.1 \%$ & 0.449 \\
Thomas & $71.4 \%$ & $82.5 \%$ & 0.084 \\
Ginsburg & $50.0 \%$ & $87.3 \%$ & 0.005 \\
\hline
\end{tabular}

123. See supra note 117 (describing how we coded the Justices' votes in cases on certiorari and on the merits).

124. See supra note 76 (discussing statistical significance; if the p-value is less than .05 , then the difference is significant at the conventional 5\% level). Of the thirteen Justices who had a lower winning percentage in high-profile cases, the drop for ten was significant at the $10 \%$ level, and for seven of those it was significant at the 5\% level. Justice Powell, on whom we had very limited data during our five sample Terms (he served during only one of those Terms), had a winning percentage of $100 \%$ in high-profile cases in our sample; he was the only Justice whose winning percentage was higher in high-profile cases than low-profile cases. 
The most obvious reason for the generally lower "win" rate in highprofile cases is that these cases are decided by closer votes on the merits than are the low-profile cases. In our five-Term sample, for instance, there were on average 6.2 votes for the majority in high-profile cases, as opposed to 7.1 votes for the majority in low-profile cases. ${ }^{125}$ This may or may not suggest that high-profile cases are harder cases, but it certainly indicates that they are more divisive cases.

But this fact still does not explain why virtually every Justice loses a higher percentage of the cases in which they would be expected to act most strategically. One possibility is that, although the Justices are voting strategically (or more so) in these cases, they have a harder time gauging their chances of winning, and so they miscalculate more often. We have assumed that the Justices are better positioned to assess their chances of winning in high-profile cases because they are more familiar with their colleagues' views in these controversial areas. But the closer votes on the merits in these cases tend to make them harder to predict, and in many of them the Justices may not know how the critical swing Justices will vote. Indeed, in some cases, the swing Justices themselves remain unsure about their own positions even after they have cast their initial votes at conference, and they do not ultimately reach a decision on the merits until the opinion writing is well underway. ${ }^{126}$

Further, victories in high-profile cases likely matter more to the Justices than victories in low-profile cases, so a Justice might be willing to take more risk in high-profile cases, because the rewards of winning are higher. In other words, even a Justice who is voting strategically might reasonably take more risks in high-profile cases, because the payoff for success is much greater. Thus, if strategic voting is occurring, it is likely to be of an even more sophisticated nature, where the Justice does not just make a simple judgment about whether he or she will win

125. In high-profile cases, there were 421 votes for the majority in 68 cases; in low-profile cases, there were 3047 votes for the majority in 428 cases. It is worth noting that our method of selecting high-profile cases may have exaggerated this difference, because the New York Times' and the Harvard Law Review's choice of leading cases to discuss may have been influenced by the closeness of the ultimate vote on the merits. See supra notes 43-47 and accompanying text (explaining our method of selecting the high-profile cases).

126. See, e.g., Jan Crawford Greenburg, Supreme Conflict 70-77, 139-60 (2007) (discussing swing Justices changing their votes on the merits after the conference in crucial situations in Planned Parenthood of Southeastern Pennsylvania v. Casey, 505 U.S. 833 (1992) (abortion); Lee v. Weisman, 505 U.S. 577 (1992) (religious freedom); and Patterson v. McLean Credit Union, 491 U.S. 164 (1989) (civil rights law), superseded by statute, Civil Rights Act of 1991, Pub. L. No. 102-166 § 101, 105 Stat. 1071, as recognized in Landgraf v. USI Film Prods., 511 U.S. 244 (1994)); John C. JefFries, JR., JustiCe Lewis F. Powell, JR. 519-30 (1994) (same for Bowers v. Hardwick, 478 U.S. 186 (1986) (gay rights), overruled by Lawrence v. Texas, 539 U.S. $558(2003))$. 
on the merits, but also considers the likelihood of winning in relation to both political (strategic) and non-political (institutional) judgments about the importance of the case and its outcome.

Our results are thus consistent with the possibility that the Justices are voting strategically in high-profile cases. Even though the more conservative Justices had a lower winning percentage in high-profile cases they voted to grant than they did in low-profile cases they voted to grant, they still were winning a large percentage of the high-profile cases-typically over $70 \% .{ }^{127}$ And the moderately conservative swing Justices in this era-Justices Powell, O'Connor, and Kennedy-were winning an even higher percentage of the high-profile cases. ${ }^{128}$ So even though the difficult terrain in these divisive cases may have caused them to fare less well than they did in low-profile cases, they were successful enough to justify a strategic aggressiveness in voting to grant the highprofile cases.

What is perhaps harder to explain on the strategic theory is the behavior of the more liberal Justices, who had the lowest winning percentages in high-profile cases that they voted to grant. ${ }^{129}$ Although these Justices were voting to grant many fewer high-profile cases than their more conservative colleagues, ${ }^{130}$ presumably for defensive reasons, ${ }^{131}$ they were still voting to grant such cases with some frequency. ${ }^{132}$ Given their dreary prospects in the high-profile cases, it may be that they were simply willing to "risk it" in cases where the outcome was at least uncertain or where a particularly compelling set of facts might sway one or more of the swing Justices to their side. And even on issues that the more liberal Justices knew they would lose, they

127. These Justices include Chief Justice Burger (70.0\%), Chief Justice Rehnquist (73.6\%), Justice Scalia (74.4\%), and Justice Thomas (71.4\%). See supra tbl.7.

128. Not surprisingly, the Justices with the highest winning percentages in high-profile cases that they voted to grant during this period are all moderates: Justices Powell $(100 \%)$, Kennedy $(87.8 \%)$, Souter $(82.1 \%)$, and O'Connor (77.9\%). See supra tbl.7; see also supra notes $69-71$ and accompanying text (discussing the ideological inclinations of the Justices in our sample).

129. These Justices (with their winning percentages in the high-profile cases that they voted to grant) included Justices Brennan (45.5\%), Marshall (46.2\%), Stevens (53.5\%), Souter (82.1\%), and Ginsburg (50.0\%). See supra tbl.7.

130. See supra tbl.2 (setting out the frequency with which individual Justices voted to grant cases).

131. See supra note 36 and accompanying text (discussing the strategic use of "defensive denials"); see also MURPHY, supra note 53, at 29 ("It would also be difficult to deny that a policyoriented Justice may believe more strongly in self-restraint when his views are in the minority on the Court or when he believes that his views are more likely to triumph ultimately if the Court allows other government officials responsibility for choice.").

132. The grant rates in high-profile cases for these Justices are as follows: Justices Brennan (48.0\%), Marshall (45.9\%), Stevens (54.9\%), Souter (67.3\%), and Ginsburg (72.7\%). See supra tbl.2. 
still had a stake in selecting cases that would best enable them to minimize the extent of their losses.

Another possibility, of course, is that the Justices were voting to grant at least some of the high-profile cases based on their sense of the Court's institutional responsibilities, even though they recognized that they were likely to lose on the merits. This would not be strategic behavior, but rather would reflect a view that despite one's own deep convictions about the issues, in some cases it is the Court's duty to step up and resolve pressing issues of social or national concern. In addition, in the group of high-profile cases where the Justices are uncertain about the outcome on the merits (because, for example, the swing Justices themselves are unsure how they will vote), institutional considerations may take on greater importance. In these cases, where the issue is of great national interest but neither side can predict the outcome, the Justices may vote to grant because institutional considerations impel them to do so. A glance through Appendix A, which sets out the Justices' case selection votes in all of the high-profile cases, supports the view that the Justices' decisional calculus includes not merely strategy, but is a much more complicated mix of strategic, institutional, and jurisprudential considerations.

Interestingly, and quite surprisingly, we found that the individual Justices' winning percentage on the merits was virtually the same regardless of whether they voted to grant or deny review at the certiorari stage. In the five Terms in our sample, this was true both for all cases and for the high-profile cases. Table 8, below, compares each Justice's winning percentages in all cases granted (regardless of whether the Justice voted to grant or deny certiorari) to the Justice's winning percentage in cases he or she voted to grant.

Table 8: Percentage of Cases in Which Justice Voted to Grant and Won on Merits Versus Percentage of All Cases in Which Justice Won on Merits Regardless of Certiorari Vote

\begin{tabular}{lllll}
\hline Justice & $\begin{array}{l}\text { High-Profile: } \\
\text { \% of All } \\
\text { Cases in } \\
\text { Which Justice } \\
\text { Won }\end{array}$ & $\begin{array}{l}\text { High-Profile: } \\
\text { \% Justice } \\
\text { Voted to } \\
\text { Grant then } \\
\text { Won }\end{array}$ & $\begin{array}{l}\text { Low-Profile: } \\
\text { \% of All Cases } \\
\text { in Which } \\
\text { Justice Won }\end{array}$ & $\begin{array}{l}\text { Low Profile: } \\
\text { \% Justice } \\
\text { Voted to } \\
\text { Grant then } \\
\text { Won }\end{array}$ \\
\hline Overall & $69.6 \%$ & $71.6 \%$ & $80.6 \%$ & $82.6 \%$ \\
Burger & $61.5 \%$ & $70.0 \%$ & $90.2 \%$ & $90.0 \%$ \\
Brennan & $45.5 \%$ & $45.5 \%$ & $64.2 \%$ & $72.9 \%$ \\
\hline
\end{tabular}


Table 8 (continued)

\begin{tabular}{lllll}
\hline Justice & $\begin{array}{l}\text { High-Profile: } \\
\text { \%of All } \\
\text { Cases in } \\
\text { Which Justice } \\
\text { Won }\end{array}$ & $\begin{array}{l}\text { High-Profile: } \\
\text { \% Justice } \\
\text { Voted to } \\
\text { Grant then } \\
\text { Won }\end{array}$ & $\begin{array}{l}\text { Low-Profile: } \\
\text { \% of All Cases } \\
\text { in Which } \\
\text { Justice Won }\end{array}$ & $\begin{array}{l}\text { Low Profile: } \\
\text { \% Justice } \\
\text { Voted to } \\
\text { Grant then } \\
\text { Won }\end{array}$ \\
\hline White & $76.9 \%$ & $76.1 \%$ & $88.9 \%$ & $88.9 \%$ \\
Marshall & $45.5 \%$ & $46.2 \%$ & $62.4 \%$ & $68.5 \%$ \\
Blackmun & $60.6 \%$ & $64.3 \%$ & $72.5 \%$ & $72.6 \%$ \\
Powell & $75.0 \%$ & $100 \%$ & $87.8 \%$ & $88.4 \%$ \\
Rehnquist & $71.8 \%$ & $73.6 \%$ & $85.3 \%$ & $87.6 \%$ \\
Stevens & $54.9 \%$ & $53.5 \%$ & $69.3 \%$ & $70.6 \%$ \\
O'Connor & $78.9 \%$ & $77.9 \%$ & $85.2 \%$ & $85.1 \%$ \\
Scalia & $77.6 \%$ & $74.4 \%$ & $85.2 \%$ & $86.2 \%$ \\
Kennedy & $89.7 \%$ & $87.8 \%$ & $92.8 \%$ & $93.5 \%$ \\
Souter & $78.9 \%$ & $82.1 \%$ & $85.0 \%$ & $83.1 \%$ \\
Thomas & $76.3 \%$ & $71.4 \%$ & $80.0 \%$ & $82.5 \%$ \\
Ginsburg & $54.5 \%$ & $50.0 \%$ & $87.5 \%$ & $87.3 \%$ \\
\hline
\end{tabular}

These figures suggest that whether a Justice is trying to secure plenary review of a case, trying to prevent it, or remaining on the sidelines has little bearing on whether the Justice will win on the merits. This may simply reflect that a Justice's chances of ultimate success are dictated by the Court's composition, and have little to do with which Justices selected the case for review. In other words, the forces at work at the merits stage may limit the effectiveness of the Justices' efforts to act strategically at the certiorari stage.

Nevertheless, if strategic considerations are driving the Justices, and if this is especially so in high-profile cases, then it is odd that the Justices do not win more cases in which they supported review than they do cases in which they opposed it. These results thus may be further evidence that the Justices are acting with a greater sense of institutional or judicial responsibility than the conventional wisdom suggests, in both highprofile and low-profile cases. 


\section{CONCLUSION}

To the American public, the Supreme Court often seems to be in the center of the social and political fray, especially in June when the Court releases decision after decision in highly controversial, ideologicallycharged cases. Although these high-profile cases make up only a small percentage of the Court's workload, they dominate the public's view of the Court, shaping not only the Court's image, but also the country's debate on divisive issues such as abortion, civil rights, religious freedom, and the distribution of political power.

In this Article, we considered whether the Justices depart from their usual case selection criteria when they are faced with cases presenting high-profile issues. Using data on the Justices' certiorari votes from the private papers of retired Justices, we compared the Justices' voting patterns on certiorari in high-profile cases to their voting patterns in lowprofile cases. Through this comparison, we assessed whether, in making the very significant initial decision to place high-profile cases on the Court's agenda, the Justices act more strategically, less strategically, or in much the same way that they approach all cases.

We found substantial evidence that the Justices act more strategically — with a closer eye to whether they will win on the meritsin voting to grant high-profile cases. During the conservative period of the Court that we canvassed, conservative Justices tended to vote to grant high-profile cases at a greater rate than liberal Justices did; the Justices were markedly more reluctant to grant high-profile cases with a mere four votes; and at least at the extremes, ideologically-aligned Justices tended to vote together more frequently on certiorari in high-profile cases, while ideologically-opposed Justices tended to vote together less frequently on certiorari in high-profile cases.

But when we tracked the individual Justices' votes from certiorari through the merits, we found that the Justices who voted to grant ultimately voted to reverse in virtually the same percentage of highprofile as low-profile cases, suggesting that they were employing a similar approach in the two sets of cases. Moreover, Justices who voted to grant won on the merits significantly less often in the high-profile cases that they voted to grant than they did in the low-profile cases that they voted to grant. Indeed, most of the liberal-leaning Justices were winning only around half of the high-profile cases that they had voted to grant. Further, the individual Justices' winning percentage on the merits was virtually the same regardless of whether they voted to grant or deny certiorari. These results strongly suggest that when the Justices are deciding whether to review high-profile cases, their decisionmaking goes 
well beyond a simple strategic calculation of the likelihood of winning on the merits. In addition to the difficulty of factoring in strategic considerations effectively, these results suggest that the Justices are also concerned with other factors, such as the institutional standing of the Court and the integrity of its judicial processes. 
APPENDIX A

Certiorari Votes in High-Profile Cases ${ }^{*}$

\begin{tabular}{|l|c|c|c|c|c|c|c|c|c|c|}
\hline \multicolumn{1}{|c|}{$\begin{array}{c}\text { Cases Granted in the } \\
\text { 1983 Term }\end{array}$} & WB & WJB & BRW & TM & HAB & LFP & WHR & JPS & SOC & $\Sigma$ \\
\hline $\begin{array}{l}\text { Hawaii Housing Auth. v. } \\
\text { Midkiff, 467 U.S. 229 (1984) }\end{array}$ & N & N & N & & N & N & N & N & N & 8 \\
\hline $\begin{array}{l}\text { Ruckelshaus v. Monsanto } \\
\text { Co., 467 U.S. 986 (1984) }\end{array}$ & N & N & & N & N & N & N & N & N & 8 \\
\hline $\begin{array}{l}\text { INS v. Lopez-Mendoza, 468 } \\
\text { U.S. 1032 (1984) }\end{array}$ & & & G & & G & & G & G & J & 5 \\
\hline $\begin{array}{l}\text { Berkemer v. McCarty, 468 } \\
\text { U.S. 420 (1984) }\end{array}$ & G & & G & & G & G & G & & & 5 \\
\hline $\begin{array}{l}\text { New Jersey v. T.L.O., 468 } \\
\text { U.S. 1214 (1984) }\end{array}$ & & & G & & G & J & G & & G & 5 \\
\hline $\begin{array}{l}\text { Roberts v. U.S. Jaycees, 498 } \\
\text { U.S. 609 (1984) }\end{array}$ & $\mathrm{N}$ & $\mathrm{N}$ & $\mathrm{N}$ & $\mathrm{N}$ & $\mathrm{N}$ & $\mathrm{N}$ & $\mathrm{N}$ & $\mathrm{N}$ & $\mathrm{N}$ & 9 \\
\hline $\begin{array}{l}\text { Garcia v. San Antonio } \\
\text { Metro. Transit Auth., 469 } \\
\text { U.S. 528 (1985) }\end{array}$ & $\mathrm{N}$ & $\mathrm{N}$ & $\mathrm{N}$ & $\mathrm{N}$ & $\mathrm{N}$ & $\mathrm{N}$ & $\mathrm{N}$ & & $\mathrm{N}$ & 8 \\
\hline $\begin{array}{l}\text { Dun \& Bradstreet, Inc. v. } \\
\text { Greenmoss Bldrs., Inc., } \\
\text { 472 U.S. 749 (1985) }\end{array}$ & $\mathrm{G}$ & $\mathrm{G}$ & $\mathrm{G}$ & $\mathrm{G}$ & & $\mathrm{G}$ & & & & 5 \\
\hline $\begin{array}{l}\text { Oregon v. Elstad, 470 U.S. } \\
\text { 298 (1985) }\end{array}$ & $\mathrm{G}$ & & & & $\mathrm{J}$ & & $\mathrm{G}$ & & $\mathrm{G}$ & 4 \\
\hline $\begin{array}{l}\text { Wallace v. Jaffree, 472 U.S. } \\
\text { 38 (1985) }\end{array}$ & $\mathrm{N}$ & & $\mathrm{N}$ & & & $\mathrm{N}$ & $\mathrm{N}$ & $\mathrm{N}$ & $\mathrm{N}$ & 6 \\
\hline $\begin{array}{l}\text { Grand Rapids Sch. Dist. v. } \\
\text { Ball, 473 U.S. 373 (1985) }\end{array}$ & $\mathrm{G}$ & & $\mathrm{G}$ & & & & $\mathrm{G}$ & & $\mathrm{J}$ & 4 \\
\hline $\begin{array}{l}\text { Fed. Election Comm'n v. } \\
\text { Nat'1 Conservative Political } \\
\text { Action Comm., 470 U.S. 480 } \\
\text { (1985) }\end{array}$ & $\mathrm{N}$ & $\mathrm{N}$ & $\mathrm{N}$ & $\mathrm{N}$ & & $\mathrm{N}$ & $\mathrm{N}$ & $\mathrm{N}$ & $\mathrm{N}$ & 8 \\
\hline $\begin{array}{l}\text { Tennessee v. Garner, 471 } \\
\text { U.S. 1 (1985) }\end{array}$ & $\mathrm{N}$ & & $\mathrm{N}$ & & & $\mathrm{J}$ & $\mathrm{N}$ & $\mathrm{N}$ & & 5 \\
\hline $\begin{array}{l}\text { Thornton v. Caldor, 472 U.S. } \\
\text { 703 (1985) }\end{array}$ & $\mathrm{G}$ & $\mathrm{G}$ & $\mathrm{G}$ & $\mathrm{G}$ & $\mathrm{G}$ & $\mathrm{G}$ & & $\mathrm{G}$ & 7 \\
\hline
\end{tabular}

* The Justices are listed in order of seniority by their initials: Warren Burger (WB); William H. Rehnquist (WHR); William J. Brennan (WJB); Byron R. White (BRW); Thurgood Marshall (TM); Harry A. Blackmun (HAB); Lewis F. Powell (LFP); John Paul Stevens (JPS); Sandra Day O’Connor (SOC); Antonin Scalia (AS); Anthony M. Kennedy (AMK); David Souter (DS); Clarence Thomas (CT); Ruth Bader Ginsburg (RBG).

The Justices' votes are identified as follows: $\mathrm{G}$ (grant), N (note jurisdiction), P (postpone consideration of jurisdiction), J (join 3), and blank (deny). $\sum$ is the total number of $\mathrm{G}, \mathrm{N}, \mathrm{P}$, and $\mathrm{J}$ votes per case. 


\begin{tabular}{|c|c|c|c|c|c|c|c|c|c|c|}
\hline $\begin{array}{c}\text { Cases Granted in the } \\
1984 \text { Term }\end{array}$ & WB & WJB & BRW & TM & $\mathrm{HAB}$ & LFP & WHR & JPS & $\mathrm{SOC}$ & $\sum$ \\
\hline $\begin{array}{l}\text { W. Air Lines v. Criswell, } \\
472 \text { U.S. } 400 \text { (1985) } \\
\end{array}$ & $\mathrm{G}$ & & $\mathrm{G}$ & & G & & G & & $\mathrm{J}$ & 5 \\
\hline $\begin{array}{l}\text { Aguilar v. Felton, } 473 \text { U.S. } \\
402 \text { (1985) }\end{array}$ & $\mathrm{N}$ & & $\mathrm{N}$ & $\mathrm{N}$ & $\mathrm{N}$ & $\mathrm{N}$ & $\mathrm{N}$ & $\mathrm{N}$ & $\mathrm{N}$ & 8 \\
\hline $\begin{array}{l}\text { City of Cleburne v. Cleburne } \\
\text { Living Ctr., } 473 \text { U.S. } 432 \\
(1985)\end{array}$ & $\mathrm{G}$ & & $\mathrm{J}$ & & $\mathrm{J}$ & & G & & G & 5 \\
\hline $\begin{array}{l}\text { Batson v. Kentucky, } 476 \\
\text { U.S. } 79 \text { (1986) } \\
\end{array}$ & & G & G & & G & G & & $\mathrm{G}$ & & 5 \\
\hline $\begin{array}{l}\text { Thornburgh v. Am. College } \\
\text { of Obstetricians \& } \\
\text { Gynecologists, } 476 \text { U.S. } 747 \\
(1986)\end{array}$ & $\mathrm{P}$ & & $\mathrm{P}$ & & & & $P$ & & $\mathrm{P}$ & 4 \\
\hline $\begin{array}{l}\text { Vasquez v. Hillery, } 747 \text { U.S. } \\
254 \text { (1986) }\end{array}$ & $\mathrm{G}$ & & $\mathrm{G}$ & & & & G & & $\mathrm{G}$ & 4 \\
\hline $\begin{array}{l}\text { Goldman v. Weinberger, } 475 \\
\text { U.S. } 503 \text { (1986) }\end{array}$ & $\mathrm{G}$ & & G & & G & G & & & G & 5 \\
\hline \begin{tabular}{|l|} 
Davis v. Bandemer, 478 U.S. \\
109 (1986)
\end{tabular} & $\mathrm{N}$ & $\mathrm{N}$ & $\mathrm{N}$ & $\mathrm{N}$ & $\mathrm{N}$ & & $\mathrm{N}$ & $\mathrm{N}$ & $\mathrm{N}$ & 8 \\
\hline $\begin{array}{l}\text { Wygant v. Jackson Bd. of } \\
\text { Educ., } 476 \text { U.S. } 267 \text { (1986) }\end{array}$ & $\mathrm{J}$ & & G & & & $\mathrm{J}$ & G & & $\mathrm{G}$ & 5 \\
\hline \begin{tabular}{|l|} 
City of Renton v. Playtime \\
Theatres, 475 U.S. 41 (1986) \\
\end{tabular} & $\mathrm{N}$ & & $\mathrm{N}$ & & & $\mathrm{N}$ & $\mathrm{N}$ & $\mathrm{N}$ & & 5 \\
\hline $\begin{array}{l}\text { Moran v. Burbine, } 475 \text { U.S. } \\
412 \text { (1986) }\end{array}$ & $\mathrm{G}$ & & G & & $\mathrm{J}$ & & G & & G & 5 \\
\hline $\begin{array}{l}\text { Philadelphia Newspapers v. } \\
\text { Hepps, } 475 \text { U.S. } 767 \text { (1986) }\end{array}$ & & & $\mathrm{N}$ & $\mathrm{P}$ & $\mathrm{N}$ & $\mathrm{N}$ & & $\mathrm{N}$ & $\mathrm{N}$ & 6 \\
\hline $\begin{array}{l}\text { Turner v. Murray, } 476 \text { U.S. } \\
28 \text { (1986) }\end{array}$ & & $\mathrm{G}$ & & $\mathrm{G}$ & G & & & $\mathrm{G}$ & $\mathrm{G}$ & 5 \\
\hline
\end{tabular}




\begin{tabular}{|c|c|c|c|c|c|c|c|c|c|c|}
\hline $\begin{array}{c}\text { Cases Granted in the } \\
1985 \text { Term }\end{array}$ & WB & WJB & BRW & TM & HAB & LFP & WHR & JPS & $\mathrm{SOC}$ & $\sum$ \\
\hline $\begin{array}{l}\text { Press-Enterprise v. Super. } \\
\text { Ct., } 478 \text { U.S. } 1 \text { (1986) }\end{array}$ & & G & $\mathrm{G}$ & $\mathrm{G}$ & $\mathrm{J}$ & & & & & 4 \\
\hline $\begin{array}{l}\text { Local } 28 \text { of the Sheet Metal } \\
\text { Workers' Int'l. Ass'n. v. } \\
\text { E.E.O.C., } 478 \text { U.S. } 421 \\
(1986)\end{array}$ & G & & G & & & G & $\mathrm{G}$ & & & 4 \\
\hline $\begin{array}{l}\text { Bethel Sch. Dist. v. Fraser, } \\
478 \text { U.S. } 675 \text { (1986) } \\
\end{array}$ & G & & & & $\mathrm{J}$ & G & $\mathrm{G}$ & & $\mathrm{G}$ & 5 \\
\hline $\begin{array}{l}\text { Lockhart v. McCree, } 476 \\
\text { U.S. } 162 \text { (1986) }\end{array}$ & G & & G & & G & G & G & $\mathrm{G}$ & $\mathrm{G}$ & 7 \\
\hline $\begin{array}{l}\text { Meritor Savings Bank v. } \\
\text { Vinson, } 477 \text { U.S. } 57 \text { (1986) }\end{array}$ & & G & $\mathrm{G}$ & & $\mathrm{G}$ & G & $\mathrm{G}$ & G & $\mathrm{G}$ & 7 \\
\hline $\begin{array}{l}\text { Local 93, Int'l. Ass'n. of } \\
\text { Firefighters v. Cleveland, } \\
478 \text { U.S. } 501 \text { (1986) }\end{array}$ & G & & $\mathrm{G}$ & & & G & $\mathrm{G}$ & & $\mathrm{G}$ & 5 \\
\hline \begin{tabular}{|l} 
Bowers v. Hardwick, 478 \\
U.S. 186 (1986)
\end{tabular} & G & & $\mathrm{G}$ & $\mathrm{G}$ & & & $\mathrm{G}$ & & & 4 \\
\hline $\begin{array}{l}\text { Arcara v. Cloud Books, } 478 \\
\text { U.S. } 697 \text { (1986) }\end{array}$ & $\mathrm{G}$ & & & & & $\mathrm{G}$ & $\mathrm{G}$ & & $\mathrm{J}$ & 4 \\
\hline $\begin{array}{l}\text { Bowsher v. Synar, } 478 \text { U.S. } \\
714 \text { (1986) }\end{array}$ & $\mathrm{N}$ & $\mathrm{N}$ & $\mathrm{N}$ & $\mathrm{N}$ & $\mathrm{N}$ & $\mathrm{N}$ & $\mathrm{N}$ & $\mathrm{N}$ & $\mathrm{N}$ & 9 \\
\hline $\begin{array}{l}\text { Ford v. Wainwright, } 477 \\
\text { U.S. } 399(1986)\end{array}$ & & $\mathrm{G}$ & & $\mathrm{G}$ & & $\mathrm{G}$ & & & $\mathrm{G}$ & 4 \\
\hline $\begin{array}{l}\text { Tison v. Arizona, } 481 \text { U.S. } \\
137 \text { (1987) }\end{array}$ & & $\mathrm{G}$ & $\mathrm{J}$ & $\mathrm{G}$ & & & & $\mathrm{G}$ & & 4 \\
\hline \begin{tabular}{|l|} 
McCleskey v. Kemp, 481 \\
U.S. 279 (1987) \\
\end{tabular} & & G & & $\mathrm{G}$ & G & & & $\mathrm{G}$ & & 4 \\
\hline \begin{tabular}{|l|} 
Colorado v. Connelly, 479 \\
U.S. 157 (1986)
\end{tabular} & G & & $\mathrm{G}$ & & G & & $\mathrm{G}$ & & G & 5 \\
\hline \begin{tabular}{|l|} 
Tashjian v. Republican \\
Party, 479 U.S. 208 (1986)
\end{tabular} & $\mathrm{N}$ & $\mathrm{N}$ & $\mathrm{N}$ & $\mathrm{N}$ & & $\mathrm{N}$ & $\mathrm{N}$ & $\mathrm{N}$ & $\mathrm{N}$ & 8 \\
\hline $\begin{array}{l}\text { United States v. Paradise, } \\
480 \text { U.S. } 149 \text { (1987) }\end{array}$ & $\mathrm{J}$ & & $\mathrm{G}$ & & & & $\mathrm{G}$ & & $\mathrm{G}$ & 4 \\
\hline $\begin{array}{l}\text { Johnson v. Transp. Agency, } \\
480 \text { U.S. } 616 \text { (1987) }\end{array}$ & $\mathrm{G}$ & & G & & & & $\mathrm{G}$ & & $\mathrm{G}$ & 4 \\
\hline $\begin{array}{l}\text { First English Evangelical } \\
\text { Lutheran Church v. County } \\
\text { of L.A., } 482 \text { U.S. } 304 \text { (1987) }\end{array}$ & $\mathrm{N}$ & $\mathrm{N}$ & $\mathrm{N}$ & $\mathrm{N}$ & $\mathrm{N}$ & $\mathrm{N}$ & $\mathrm{N}$ & $\mathrm{N}$ & $\mathrm{N}$ & 9 \\
\hline \begin{tabular}{|l} 
Edwards v. Aguillard, 482 \\
U.S. 578 (1987)
\end{tabular} & $\mathrm{N}$ & & $\mathrm{N}$ & & & $\mathrm{N}$ & $\mathrm{N}$ & & $\mathrm{N}$ & 5 \\
\hline
\end{tabular}




\begin{tabular}{|l|c|c|c|c|c|c|c|c|c|c|}
\hline \multicolumn{1}{|c|}{$\begin{array}{c}\text { Cases Granted in the } \\
\text { 1986 Term }\end{array}$} & WHR & WJB & BRW & TM & HAB & LP & JPS & SOC & AS & S \\
\hline $\begin{array}{l}\text { United States v. Salerno, 481 } \\
\text { U.S. 739 (1987) }\end{array}$ & G & G & G & & G & G & G & G & G & 8 \\
\hline $\begin{array}{l}\text { Rivera v. Minnich, 483 U.S. } \\
\text { 574 (1987) }\end{array}$ & & N & & N & N & & N & & & 4 \\
\hline $\begin{array}{l}\text { Nollan v. Cal. Coastal } \\
\text { Comm., 483 U.S. 825 (1987) }\end{array}$ & N & & N & & & N & & N & N & 5 \\
\hline $\begin{array}{l}\text { Booth v. Maryland, 482 U.S. } \\
\text { 496 (1987) }\end{array}$ & & G & & G & G & & G & & & 4 \\
\hline $\begin{array}{l}\text { California v. Greenwood, } \\
\text { 486 U.S. 35 (1988) }\end{array}$ & G & & G & & J & G & & G & & 5 \\
\hline $\begin{array}{l}\text { Pennell v. City of San Jose, } \\
\text { 485 U.S. 1 (1988) }\end{array}$ & P & & P & & & P & N & P & P & 6 \\
\hline $\begin{array}{l}\text { Lyng v. Nw. Indian } \\
\text { Cemetery Protective Ass'n, } \\
\text { 485 U.S. 439 (1988) }\end{array}$ & G & & G & & & G & G & G & & 5 \\
\hline $\begin{array}{l}\text { Hustler Magazine v. Falwell, } \\
\text { 485 U.S. 46 (1988) }\end{array}$ & & G & G & & G & G & G & & & 5 \\
\hline $\begin{array}{l}\text { Webster v. Doe, 486 U.S. } \\
\text { 592 (1988) }\end{array}$ & G & & G & & & G & & & G & 4 \\
\hline $\begin{array}{l}\text { Watson v. Fort Worth Bank } \\
\text { \& Trust, 487 U.S. 977 (1988) }\end{array}$ & G & G & G & G & & G & & G & & 6 \\
\hline $\begin{array}{l}\text { Thompson v. Oklahoma, 487 } \\
\text { U.S. 815 (1988) }\end{array}$ & J & G & J & G & J & G & G & G & & 8 \\
\hline
\end{tabular}




\begin{tabular}{|c|c|c|c|c|c|c|c|c|c|c|}
\hline $\begin{array}{c}\text { Cases Granted in the } \\
1987 \text { Term }\end{array}$ & WHR & WJB & BRW & $\mathrm{TM}$ & $\mathrm{HAB}$ & JPS & SOC & AS & AMK & $\sum$ \\
\hline $\begin{array}{l}\text { N.Y. State Club Ass'n v. } \\
\text { City of New York, } 487 \text { U.S. } \\
1 \text { (1988) }\end{array}$ & $\mathrm{N}$ & & $\mathrm{N}$ & & & & $\mathrm{N}$ & $\mathrm{N}$ & & 4 \\
\hline $\begin{array}{l}\text { Frisby v. Schultz, } 487 \text { U.S. } \\
474 \text { (1988) }\end{array}$ & $\mathrm{P}$ & $\mathrm{P}$ & $\mathrm{P}$ & $\mathrm{P}$ & $\mathrm{P}$ & & $\mathrm{P}$ & $\mathrm{P}$ & & 7 \\
\hline $\begin{array}{l}\text { Bowen v. Kendrick, } 487 \\
\text { U.S. } 589 \text { (1988) }\end{array}$ & $\mathrm{N}$ & $\mathrm{N}$ & $\mathrm{N}$ & $\mathrm{N}$ & & $\mathrm{N}$ & & $\mathrm{N}$ & & 6 \\
\hline $\begin{array}{l}\text { Morrison v. Olson, } 487 \text { U.S. } \\
654 \text { (1988) }\end{array}$ & $\mathrm{N}$ & $\mathrm{N}$ & $\mathrm{N}$ & $\mathrm{N}$ & $\mathrm{N}$ & $\mathrm{N}$ & $\mathrm{N}$ & $\mathrm{N}$ & & 8 \\
\hline $\begin{array}{l}\text { Nat'l Treasury Employees } \\
\text { Union v. Von Raab, } 489 \\
\text { U.S. } 656 \text { (1989) }\end{array}$ & $\mathrm{G}$ & $\mathrm{G}$ & $\mathrm{G}$ & G & G & & $\mathrm{G}$ & G & $\mathrm{G}$ & 8 \\
\hline $\begin{array}{l}\text { Patterson v. McClean Credit } \\
\text { Union, 491 U.S. } 164 \text { (1989) }\end{array}$ & & $\mathrm{G}$ & $\mathrm{G}$ & $\mathrm{G}$ & & G & & & & 4 \\
\hline $\begin{array}{l}\text { DeShaney v. Winnebago } \\
\text { County Dep't of Soc. Servs., } \\
489 \text { U.S. } 189 \text { (1989) }\end{array}$ & & $\mathrm{G}$ & $\mathrm{G}$ & G & $\mathrm{J}$ & & & & & 4 \\
\hline \begin{tabular}{|l|} 
Fort Wayne Books, Inc. v. \\
Indiana, 489 U.S. 46 (1989) \\
\end{tabular} & & $\mathrm{G}$ & G & $\mathrm{G}$ & $\mathrm{G}$ & G & & & & 5 \\
\hline $\begin{array}{l}\text { Michael H. v. Gerald D., } \\
491 \text { U.S. } 110 \text { (1989) }\end{array}$ & & $\mathrm{N}$ & $\mathrm{N}$ & & $\mathrm{J}$ & & $\mathrm{J}$ & & $\mathrm{N}$ & 5 \\
\hline $\begin{array}{l}\text { City of Richmond v. J.A. } \\
\text { Croson Co., } 488 \text { U.S. } 469 \\
(1989)\end{array}$ & $\mathrm{N}$ & $\mathrm{N}$ & $\mathrm{N}$ & $\mathrm{N}$ & $\mathrm{J}$ & $\mathrm{N}$ & $\mathrm{N}$ & $\mathrm{N}$ & $\mathrm{N}$ & 9 \\
\hline $\begin{array}{l}\text { Price Waterhouse v. } \\
\text { Hopkins, } 490 \text { U.S. } 228 \\
(1989)\end{array}$ & $\mathrm{G}$ & $\mathrm{G}$ & $\mathrm{G}$ & $\mathrm{G}$ & G & & $\mathrm{J}$ & & G & 7 \\
\hline $\begin{array}{l}\text { Pennsylvania v. Union Gas } \\
\text { Co., } 491 \text { U.S. } 1 \text { (1989) }\end{array}$ & $\mathrm{G}$ & & $\mathrm{J}$ & & & & $\mathrm{G}$ & G & G & 5 \\
\hline $\begin{array}{l}\text { Texas Monthly, Inc. v. } \\
\text { Bullock, } 489 \text { U.S. } 1 \text { (1989) }\end{array}$ & $\mathrm{N}$ & $\mathrm{N}$ & & $\mathrm{N}$ & $\mathrm{N}$ & $\mathrm{N}$ & $\mathrm{N}$ & $\mathrm{N}$ & $\mathrm{N}$ & 8 \\
\hline \begin{tabular}{|l|} 
Wards Cove Packing Co. v. \\
Atonio, 490 U.S. 642 (1989) \\
\end{tabular} & $\mathrm{G}$ & & G & & & & $\mathrm{G}$ & $\mathrm{G}$ & G & 5 \\
\hline $\begin{array}{l}\text { Skinner v. Ry. Labor } \\
\text { Executives Ass'n., } 489 \text { U.S. } \\
602 \text { (1989) }\end{array}$ & $\mathrm{G}$ & $\mathrm{G}$ & $\mathrm{G}$ & $\mathrm{G}$ & $\mathrm{G}$ & G & $\mathrm{G}$ & $\mathrm{G}$ & $\mathrm{G}$ & 9 \\
\hline $\begin{array}{l}\text { Martin v. Wilks, } 490 \text { U.S. } \\
755 \text { (1989) }\end{array}$ & $\mathrm{G}$ & & $\mathrm{G}$ & G & G & G & $\mathrm{G}$ & G & G & 8 \\
\hline $\begin{array}{l}\text { Penry v. Lynaugh, } 492 \text { U.S. } \\
302 \text { (1989) }\end{array}$ & $\mathrm{G}$ & $\mathrm{G}$ & & $\mathrm{G}$ & G & G & $\mathrm{G}$ & G & G & 8 \\
\hline $\begin{array}{l}\text { Mistretta v. United States, } \\
488 \text { U.S. } 361(1989) \\
\end{array}$ & G & $\mathrm{G}$ & G & $\mathrm{G}$ & $\mathrm{G}$ & G & G & G & $\mathrm{G}$ & 9 \\
\hline
\end{tabular}




\begin{tabular}{|c|c|c|c|c|c|c|c|c|c|c|}
\hline $\begin{array}{c}\text { Cases Granted in the } \\
1988 \text { Term }\end{array}$ & WHR & WJB & BRW & $\mathrm{TM}$ & HAB & JPS & $\mathrm{SOC}$ & AS & AMK & $\sum$ \\
\hline $\begin{array}{l}\text { The Florida Star v. BJF, } \\
491 \text { U.S. } 524 \text { (1989) }\end{array}$ & $\mathrm{N}$ & $\mathrm{N}$ & $\mathrm{N}$ & $\mathrm{N}$ & $\mathrm{P}$ & & $\mathrm{P}$ & $\mathrm{N}$ & $\mathrm{N}$ & 8 \\
\hline $\begin{array}{l}\text { Frazee v. Ill. Dep't of } \\
\text { Employment Sec., } 489 \text { U.S. } \\
829(1989)\end{array}$ & $\mathrm{N}$ & & $\mathrm{N}$ & & & & $\mathrm{N}$ & $\mathrm{N}$ & $\mathrm{N}$ & 5 \\
\hline $\begin{array}{l}\text { County of Allegheny v. } \\
\text { ACLU Greater Pittsburgh } \\
\text { Chapter, } 492 \text { U.S. } 573 \\
(1989)\end{array}$ & $\mathrm{G}$ & & G & & & & & $\mathrm{G}$ & G & 4 \\
\hline $\begin{array}{l}\text { Stanford v. Kentucky, } 492 \\
\text { U.S. } 361 \text { (1989) }\end{array}$ & & & G & G & G & G & & & & 4 \\
\hline $\begin{array}{l}\text { Texas v. Johnson, } 491 \text { U.S. } \\
397 \text { (1989) }\end{array}$ & $\mathrm{G}$ & & G & & & & G & $\mathrm{G}$ & $\mathrm{G}$ & 5 \\
\hline $\begin{array}{l}\text { Sable Commc'ns of Cal., } \\
\text { Inc. v. F.C.C., } 492 \text { U.S. } 115 \\
(1989)\end{array}$ & $\mathrm{N}$ & $\mathrm{N}$ & $\mathrm{N}$ & $\mathrm{N}$ & $\mathrm{N}$ & $\mathrm{N}$ & $\mathrm{N}$ & $\mathrm{N}$ & $\mathrm{N}$ & 9 \\
\hline $\begin{array}{l}\text { Browning-Ferris Indus. of } \\
\text { Vt., Inc. v. Kelco Disposal, } \\
\text { Inc., } 492 \text { U.S. } 257 \text { (1989) }\end{array}$ & G & & G & & $\mathrm{G}$ & & $\mathrm{G}$ & $\mathrm{G}$ & & 5 \\
\hline $\begin{array}{l}\text { Webster v. Reprod. Health } \\
\text { Servs., } 492 \text { U.S. } 490 \text { (1989) }\end{array}$ & $\mathrm{N}$ & & $\mathrm{N}$ & & & $\mathrm{N}$ & $\mathrm{N}$ & $\mathrm{N}$ & $\mathrm{N}$ & 6 \\
\hline $\begin{array}{l}\text { Ohio v. Akron Ctr. for } \\
\text { Reprod. Health, } 497 \text { U.S. } \\
502 \text { (1990) }\end{array}$ & $\mathrm{N}$ & & $\mathrm{N}$ & & & & $\mathrm{N}$ & $\mathrm{N}$ & $\mathrm{N}$ & 5 \\
\hline $\begin{array}{l}\text { Spallone v. United States, } \\
493 \text { U.S. } 265 \text { (1990) }\end{array}$ & $\mathrm{G}$ & & G & & & & G & $\mathrm{G}$ & G & 5 \\
\hline $\begin{array}{l}\text { Hodgson v. Minnesota, } 497 \\
\text { U.S. } 417 \text { (1990) }\end{array}$ & G & $\mathrm{G}$ & G & G & G & $\mathrm{G}$ & $\mathrm{G}$ & & G & 8 \\
\hline $\begin{array}{l}\text { Missouri v. Jenkins, } 495 \\
\text { U.S. } 33 \text { (1990) }\end{array}$ & $\mathrm{G}$ & G & G & G & & G & & $\mathrm{G}$ & & 6 \\
\hline $\begin{array}{l}\text { Employment Div. v. Smith, } \\
494 \text { U.S. } 872 \text { (1990) }\end{array}$ & $\mathrm{G}$ & & $\mathrm{J}$ & & & G & G & $\mathrm{G}$ & & 5 \\
\hline $\begin{array}{l}\text { United States v. Verdugo- } \\
\text { Urquidez, } 494 \text { U.S. } 259 \\
\text { (1990) }\end{array}$ & $\mathrm{G}$ & $\mathrm{G}$ & G & G & $\mathrm{G}$ & G & $\mathrm{G}$ & $\mathrm{G}$ & $\mathrm{G}$ & 9 \\
\hline $\begin{array}{l}\text { Jimmy Swaggart Ministries } \\
\text { v. Bd. of Equalization, } 493 \\
\text { U.S. } 378 \text { (1990) }\end{array}$ & $\mathrm{N}$ & & & & $\mathrm{N}$ & $\mathrm{N}$ & $\mathrm{N}$ & $\mathrm{N}$ & $\mathrm{N}$ & 6 \\
\hline $\begin{array}{l}\text { Cruzan v. Dir., Mo. Dep’t } \\
\text { of Health, } 497 \text { U.S. } 261 \\
(1990)\end{array}$ & & & & & G & $\mathrm{G}$ & & $\mathrm{G}$ & $\mathrm{G}$ & 4 \\
\hline \begin{tabular}{|l|} 
Austin v. Mich. Chamber of \\
Commerce, 494 U.S. 652 \\
$(1990)$
\end{tabular} & $\mathrm{N}$ & $\mathrm{N}$ & $\mathrm{N}$ & $\mathrm{N}$ & $\mathrm{N}$ & $\mathrm{N}$ & $\mathrm{N}$ & & $\mathrm{N}$ & 8 \\
\hline $\begin{array}{l}\text { Bd. of Educ. v. Mergens, } \\
496 \text { U.S. } 226(1990)\end{array}$ & $\mathrm{J}$ & & $\mathrm{G}$ & & $\mathrm{J}$ & G & G & & G & 6 \\
\hline
\end{tabular}




\begin{tabular}{|l|c|c|c|c|c|c|c|c|c|c|}
\hline $\begin{array}{l}\text { Cases Granted in the } \\
\text { 1988 Term (continued) }\end{array}$ & WHR & WJB & BRW & TM & HAB & JPS & SOC & AS & AMK & $\sum$ \\
\hline $\begin{array}{l}\text { Holland v. Illinois, 493 } \\
\text { U.S. 474 (1990) }\end{array}$ & G & G & G & G & G & G & G & G & G & 9 \\
\hline $\begin{array}{l}\text { Osborne v. Ohio, 495 U.S. } \\
103 \text { (1990) }\end{array}$ & N & N & N & N & & N & N & N & N & 8 \\
\hline
\end{tabular}

\begin{tabular}{|l|c|c|c|c|c|c|c|c|c|c|}
\hline \multicolumn{1}{|c|}{$\begin{array}{c}\text { Cases Granted in the } \\
\text { 1989 Term }\end{array}$} & WHR & WJB & BRW & TM & HAB & JPS & SOC & AS & AMK & I \\
\hline $\begin{array}{l}\text { Rutan v. Republican Party } \\
\text { of Ill., 497 U.S. 62 (1990) }\end{array}$ & & G & G & G & G & G & G & & G & 7 \\
\hline $\begin{array}{l}\text { Mich. Dep't of State Police } \\
\text { v. Sitz, 496 U.S. 444 (1990) }\end{array}$ & G & & G & & G & & G & & & 4 \\
\hline $\begin{array}{l}\text { Pennsylvania v. Muniz, 496 } \\
\text { U.S. 582 (1990) }\end{array}$ & G & & G & & J & & G & & G & 5 \\
\hline $\begin{array}{l}\text { Metro Broad., Inc. v. FCC, } \\
\text { 497 U.S. 547 (1990) }\end{array}$ & G & G & G & G & G & G & G & G & G & 9 \\
\hline $\begin{array}{l}\text { Milkovich v. Lorain Journal } \\
\text { Co., 497 U.S. 1 (1990) }\end{array}$ & G & & G & & & & & G & G & 4 \\
\hline $\begin{array}{l}\text { Arizona v. Fulminate, 499 } \\
\text { U.S. 279 (1991) }\end{array}$ & G & G & G & G & J & & G & & G & 7 \\
\hline $\begin{array}{l}\text { Bd. of Educ. v. Dowell, 498 } \\
\text { U.S. 237 (1991) }\end{array}$ & G & & G & & G & & G & & & 4 \\
\hline $\begin{array}{l}\text { UAW v. Johnson Controls, } \\
\text { Inc., 499 U.S. 187 (1991) }\end{array}$ & & & G & & J & G & G & G & & 5 \\
\hline $\begin{array}{l}\text { Pac. Mut. Life Ins. Co. v. } \\
\text { Haslip, 499 U.S. 1 (1991) }\end{array}$ & & J & G & & J & & G & G & G & 6 \\
\hline $\begin{array}{l}\text { Rust v. Sullivan, 500 U.S. } \\
\text { 173 (1991) }\end{array}$ & G & G & G & J & G & G & G & G & G & 9 \\
\hline $\begin{array}{l}\text { United States v. Eichman, } \\
\text { 496 U.S. 310 (1990) }\end{array}$ & N & & N & & & & N & N & N & 5 \\
\hline $\begin{array}{l}\text { Minnick v. Mississippi, 498 } \\
\text { U.S. 146 (1990) }\end{array}$ & & G & G & G & G & G & G & & & 6 \\
\hline $\begin{array}{l}\text { Powers v. Ohio, 499 U.S. } \\
\text { 400 (1991) }\end{array}$ & G & & G & G & G & G & G & G & G & 8 \\
\hline
\end{tabular}




\begin{tabular}{|c|c|c|c|c|c|c|c|c|c|c|}
\hline $\begin{array}{c}\text { Cases Granted in the } \\
1990 \text { Term } \\
\end{array}$ & WHR & BRW & $\mathrm{TM}$ & HAB & JPS & SOC & AS & AMK & DS & $\sum$ \\
\hline \begin{tabular}{|l|} 
Edmonson v. Leesville \\
Concrete Co., 500 U.S. 614 \\
$(1991)$
\end{tabular} & G & G & $\mathrm{J}$ & G & & G & G & $\mathrm{G}$ & & 7 \\
\hline $\begin{array}{l}\text { Masson v. New Yorker } \\
\text { Magazine, Inc., } 501 \text { U.S. } \\
496(1991)\end{array}$ & $\mathrm{G}$ & & & G & G & $\mathrm{G}$ & G & G & & 6 \\
\hline $\begin{array}{l}\text { Barnes v. Glen Theatre, } \\
\text { Inc., } 501 \text { U.S. } 560 \text { (1991) }\end{array}$ & $\mathrm{G}$ & $\mathrm{G}$ & & G & & G & $\mathrm{G}$ & $\mathrm{G}$ & & 6 \\
\hline $\begin{array}{l}\text { Gregory v. Ashcroft, } 501 \\
\text { U.S. } 452 \text { (1991) }\end{array}$ & $\mathrm{G}$ & G & $\mathrm{J}$ & G & & & $\mathrm{G}$ & G & G & 7 \\
\hline $\begin{array}{l}\text { Cohen v. Cowles Media } \\
\text { Co., } 501 \text { U.S. } 663 \text { (1991) } \\
\end{array}$ & G & G & & $\mathrm{J}$ & & & G & & & 4 \\
\hline \begin{tabular}{|l} 
Chisom v. Roemer, 501 \\
U.S. 380 (1991) \\
\end{tabular} & G & G & G & G & G & G & & G & G & 8 \\
\hline $\begin{array}{l}\text { Metro. Wash. Airports } \\
\text { Auth. v. Citizens for the } \\
\text { Abatement of Aircraft } \\
\text { Noise, Inc., } 501 \text { U.S. } 252 \\
(1991)\end{array}$ & G & G & $\mathrm{G}$ & G & G & G & G & $\mathrm{G}$ & G & 9 \\
\hline $\begin{array}{l}\text { Franklin v. Gwinnett } \\
\text { County Pub. Schs., } 503 \\
\text { U.S. } 60 \text { (1992) }\end{array}$ & & $\mathrm{G}$ & G & & G & $\mathrm{G}$ & & & & 4 \\
\hline $\begin{array}{l}\text { Bray v. Alexandria } \\
\text { Women's Health Clinic, } \\
506 \text { U.S. } 263 \text { (1993) } \\
\end{array}$ & $\mathrm{G}$ & G & & & & & G & G & & 4 \\
\hline $\begin{array}{l}\text { Lee v. Weisman, } 505 \text { U.S. } \\
577 \text { (1992) }\end{array}$ & $\mathrm{G}$ & G & & & & & G & G & G & 5 \\
\hline \begin{tabular}{|l} 
Burson v. Freeman, 504 \\
U.S. 191 (1992)
\end{tabular} & $\mathrm{G}$ & G & & $\mathrm{J}$ & & $\mathrm{G}$ & G & $\mathrm{G}$ & G & 7 \\
\hline $\begin{array}{l}\text { Simon \& Schuster, Inc. v. } \\
\text { N.Y. State Crime Victims } \\
\text { Bd., } 502 \text { U.S. } 105 \text { (1991) }\end{array}$ & $\mathrm{G}$ & G & & G & G & $\mathrm{G}$ & & & & 5 \\
\hline \begin{tabular}{|l|} 
United States v. Fordice, \\
505 U.S. 717 (1992) \\
\end{tabular} & G & $\mathrm{G}$ & $\mathrm{J}$ & G & G & $\mathrm{G}$ & $\mathrm{G}$ & $\mathrm{G}$ & G & 9 \\
\hline $\begin{array}{l}\text { Freeman v. Pitts, } 503 \text { U.S. } \\
467 \text { (1992) }\end{array}$ & G & G & & & & G & G & $\mathrm{G}$ & G & 6 \\
\hline \begin{tabular}{|l|} 
Payne v. Tennessee, 501 \\
U.S. 808 (1991) \\
\end{tabular} & G & G & & & & G & G & G & G & 6 \\
\hline $\begin{array}{l}\text { RAV v. St. Paul, } 505 \text { U.S. } \\
377 \text { (1992) }\end{array}$ & & G & $\mathrm{J}$ & & G & & & & & 3 \\
\hline
\end{tabular}




\begin{tabular}{|l|c|c|c|c|c|c|c|c|c|c|}
\hline \multicolumn{1}{|c|}{$\begin{array}{c}\text { Cases Granted in the } \\
\text { 1991 Term }\end{array}$} & WHR & BRW & HAB & JPS & SOC & AS & AMK & DS & CT & I \\
\hline $\begin{array}{l}\text { Nordlinger v. Hahn, 505 } \\
\text { U.S. 1 (1992) }\end{array}$ & & G & J & G & J & & G & J & & 6 \\
\hline $\begin{array}{l}\text { Lucas v. S.C. Coastal } \\
\text { Council, 505 U.S. 1003 } \\
\text { (1992) }\end{array}$ & G & G & J & & G & G & & & G & 6 \\
\hline $\begin{array}{l}\text { Burdick v. Takushi, 504 } \\
\text { U.S. 428 (1992) }\end{array}$ & & G & & G & & G & & J & G & 5 \\
\hline $\begin{array}{l}\text { New York v. United States, } \\
\text { 505 U.S. 144 (1992) }\end{array}$ & G & & & & G & G & G & G & G & 6 \\
\hline $\begin{array}{l}\text { United States v. Alvarez- } \\
\text { Machain, 504 U.S. 655 } \\
\text { (1992) }\end{array}$ & G & G & G & G & G & G & G & G & G & 9 \\
\hline $\begin{array}{l}\text { Nixon v. United States, 506 } \\
\text { U.S. 224 (1993) }\end{array}$ & & G & & & & G & G & G & G & 5 \\
\hline $\begin{array}{l}\text { Planned Parenthood of Se. } \\
\text { Pa. v. Casey, 505 U.S. 833 } \\
\text { (1992) }\end{array}$ & & G & G & G & & G & G & G & G & 7 \\
\hline $\begin{array}{l}\text { Church of the Lukumi } \\
\text { Babalu Aye, Inc. v. City of } \\
\text { Hialeah, 508 U.S. 520 } \\
\text { (1993) }\end{array}$ & & & & & & & & & & J \\
\hline $\begin{array}{l}\text { Withrow v. Williams, 507 } \\
\text { U.S. 680 (1993) }\end{array}$ & G & G & G & J & & G & G & & 6 \\
\hline $\begin{array}{l}\text { Alexander v. United States, } \\
\text { 509 U.S. 544 (1993) }\end{array}$ & & & G & J & G & G & & G & 5 \\
\hline
\end{tabular}




\begin{tabular}{|c|c|c|c|c|c|c|c|c|c|c|}
\hline $\begin{array}{c}\text { Cases Granted in the } \\
1992 \text { Term } \\
\end{array}$ & WHR & BRW & $\mathrm{HAB}$ & JPS & SOC & AS & AMK & DS & CT & $\sum$ \\
\hline $\begin{array}{l}\text { Lamb's Chapel v. Ctr. } \\
\text { Moriches Union Free Sch. } \\
\text { Dist., } 508 \text { U.S. } 384 \text { (1993) }\end{array}$ & $\mathrm{G}$ & G & $\mathrm{J}$ & & G & G & & & & 5 \\
\hline \begin{tabular}{|l|} 
Zobrest v. Catalina \\
Foothills Sch. Dist., 509 \\
U.S. 1 (1993) \\
\end{tabular} & $\mathrm{G}$ & G & & G & & & $\mathrm{J}$ & & G & 5 \\
\hline $\begin{array}{l}\text { Daubert v. Merrell Dow } \\
\text { Pharm., Inc., } 509 \text { U.S. } 579 \\
(1993)\end{array}$ & $\mathrm{G}$ & G & G & G & G & G & G & G & G & 9 \\
\hline $\begin{array}{l}\text { Sale v. Haitian Ctrs. } \\
\text { Council, Inc., } 509 \text { U.S. } 155 \\
\text { (1993) }\end{array}$ & $\mathrm{G}$ & G & $\mathrm{G}$ & G & G & G & G & $\mathrm{G}$ & G & 9 \\
\hline $\begin{array}{l}\text { Shaw v. Reno, } 509 \text { U.S. } \\
630 \text { (1993) }\end{array}$ & $\mathrm{N}$ & $\mathrm{N}$ & $\mathrm{N}$ & $\mathrm{N}$ & $\mathrm{N}$ & $\mathrm{N}$ & $\mathrm{N}$ & $\mathrm{N}$ & $\mathrm{N}$ & 9 \\
\hline \begin{tabular}{|l|} 
TXO Prod. Corp. v. \\
Alliance Res. Corp., 509 \\
U.S. 443 (1993) \\
\end{tabular} & & $\mathrm{G}$ & $\mathrm{J}$ & & G & & & G & & 4 \\
\hline $\begin{array}{l}\text { Wisconsin v. Mitchell, } 508 \\
\text { U.S. } 476 \text { (1993) }\end{array}$ & $\mathrm{G}$ & G & G & $\mathrm{G}$ & G & G & G & $\mathrm{G}$ & G & 9 \\
\hline \begin{tabular}{|l|} 
St. Mary’s Honor Ctr. v. \\
Hicks, 509 U.S. 502 (1993)
\end{tabular} & $\mathrm{G}$ & $\mathrm{G}$ & & & & G & & $\mathrm{J}$ & & 4 \\
\hline \begin{tabular}{|l|} 
Landgraf v. USI Film \\
Prods., 511 U.S. 244 (1994)
\end{tabular} & $\mathrm{G}$ & $\mathrm{G}$ & G & $\mathrm{G}$ & G & G & G & $\mathrm{G}$ & G & 9 \\
\hline $\begin{array}{l}\text { Nat'l Org. for Women, Inc. } \\
\text { v. Scheidler, } 510 \text { U.S. } 249 \\
(1994)\end{array}$ & & $\mathrm{G}$ & $\mathrm{G}$ & G & $\mathrm{J}$ & & & & & 4 \\
\hline $\begin{array}{l}\text { Rivers v. Roadway Exp., } \\
\text { Inc., } 511 \text { U.S. } 298 \text { (1994) }\end{array}$ & $\mathrm{G}$ & G & G & G & G & G & G & $\mathrm{G}$ & G & 9 \\
\hline $\begin{array}{l}\text { Harris v. Forklift Sys., Inc., } \\
510 \text { U.S. } 17 \text { (1993) }\end{array}$ & & $\mathrm{G}$ & $\mathrm{J}$ & G & G & & & & & 4 \\
\hline $\begin{array}{l}\text { United States v. James } \\
\text { Daniel Good Real Prop., } \\
510 \text { U.S. } 43 \text { (1993) } \\
\end{array}$ & $\mathrm{G}$ & & G & G & G & G & $\mathrm{G}$ & $\mathrm{G}$ & G & 8 \\
\hline \begin{tabular}{|l|} 
J.E.B. v. Alabama, 511 U.S. \\
127 (1994)
\end{tabular} & & G & $\mathrm{J}$ & $\mathrm{G}$ & $\mathrm{J}$ & G & G & $\mathrm{G}$ & & 7 \\
\hline $\begin{array}{l}\text { Campbell v. Acuff-Rose } \\
\text { Music, Inc., } 510 \text { U.S. } 569 \\
(1994)\end{array}$ & $\mathrm{J}$ & $\mathrm{G}$ & G & $\mathrm{G}$ & G & G & & $\mathrm{J}$ & & 7 \\
\hline $\begin{array}{l}\text { Waters v. Churchill, } 511 \\
\text { U.S. } 661 \text { (1994) } \\
\end{array}$ & $\mathrm{G}$ & G & & & & & & G & $\mathrm{G}$ & 4 \\
\hline $\begin{array}{l}\text { Austin v. United States, } 509 \\
\text { U.S. } 602 \text { (1993) } \\
\end{array}$ & & G & & & $\mathrm{G}$ & & & $\mathrm{G}$ & $\mathrm{J}$ & 4 \\
\hline
\end{tabular}




\begin{tabular}{|l|c|c|c|c|c|c|c|c|c|c|}
\hline \multicolumn{1}{|c|}{$\begin{array}{c}\text { Cases Granted in the } \\
\text { 1993 Term }\end{array}$} & WHR & HAB & JPS & SOC & AS & AMK & DS & CT & RBG & ( \\
\hline $\begin{array}{l}\text { Turner Broad. Sys., Inc. v. } \\
\text { FCC, 512 U.S. 622 (1994) }\end{array}$ & N & N & N & N & N & N & N & N & N & 9 \\
\hline $\begin{array}{l}\text { Dalton v. Specter, 511 U.S. } \\
\text { 462 (1994) }\end{array}$ & G & G & G & G & G & G & G & G & G & 9 \\
\hline $\begin{array}{l}\text { Bd. of Educ. of Kiryas Joel } \\
\text { Vill. Sch. Dist. v. Grumet, } \\
\text { 512 U.S. 687 (1994) }\end{array}$ & G & & & & G & G & & G & & 4 \\
\hline $\begin{array}{l}\text { Dolan v. City of Tigard, } \\
\text { 512 U.S. 374 (1994) }\end{array}$ & G & & & J & G & G & & G & & 5 \\
\hline $\begin{array}{l}\text { Honda Motor Co. v. Oberg, } \\
\text { 512 U.S. 415 (1994) }\end{array}$ & & J & G & G & & & & & G & 4 \\
\hline $\begin{array}{l}\text { Madsen v. Women's Health } \\
\text { Ctr., Inc., } \\
\text { 512 U.S. 753 (1994) }\end{array}$ & G & G & G & G & G & G & G & G & G & 9 \\
\hline $\begin{array}{l}\text { United States v. Lopez, 514 } \\
\text { U.S. 549 (1995) }\end{array}$ & G & G & G & G & G & G & G & G & G & 9 \\
\hline $\begin{array}{l}\text { McIntyre v. Ohio Elections } \\
\text { Comm'n, 514 U.S. 334 } \\
\text { (1995) }\end{array}$ & G & G & G & G & & G & G & G & & 7 \\
\hline $\begin{array}{l}\text { United States v. Nat'1 } \\
\text { Treasury Employees } \\
\text { Union, 513 U.S. 454 (1995) }\end{array}$ & G & G & G & G & G & G & G & G & G & 9 \\
\hline $\begin{array}{l}\text { Plaut v. Spendthrift Farm, } \\
\text { Inc., 514 U.S. 211 (1995) }\end{array}$ & G & G & & & G & & G & G & G & 6 \\
\hline $\begin{array}{l}\text { U.S. Term Limits, Inc. v. } \\
\text { Thornton, 514 U.S. 779 } \\
\text { (1995) }\end{array}$ & G & G & & G & G & G & G & G & G & 8 \\
\hline
\end{tabular}


APPENDIX B

Average Rate of Agreement in Votes on the Merits, ${ }^{* *}$ Certiorari in All Cases Granted, and Certiorari in High-Profile Cases

\begin{tabular}{|c|c|c|c|c|c|c|c|}
\hline Pairing & $\begin{array}{c}\text { Merits } \\
\text { Avg. }\end{array}$ & $\begin{array}{c}\text { Ordinal } \\
\text { Rank }\end{array}$ & $\begin{array}{c}\text { Cert } \\
\text { Avg. } \\
\text { (All } \\
\text { Cases) }\end{array}$ & $\begin{array}{c}\text { Ordinal } \\
\text { Rank }\end{array}$ & $\begin{array}{c}\text { High- } \\
\text { Profile } \\
\text { Avg. }\end{array}$ & $\begin{array}{c}\text { Ordinal } \\
\text { Rank }\end{array}$ & $\begin{array}{c}\text { Difference } \\
\text { Between } \\
\text { H-P Avg. } \\
\text { and All } \\
\text { Cert Avg. }\end{array}$ \\
\hline $\begin{array}{l}\text { Brennan } \\
\text { Marshall }\end{array}$ & $95.0 \%$ & 1 & $80.7 \%$ & 1 & $87.0 \%$ & 2 & $6.3 \%$ \\
\hline $\begin{array}{l}\text { Burger } \\
\text { Rehnquist }\end{array}+$ & $89.5 \%$ & 2 & $67.8 \%$ & 14 & $86.0 \%$ & 3 & $18.2 \%$ \\
\hline $\begin{array}{l}\text { Burger } \\
\text { O'Connor }\end{array}$ & $87.6 \%$ & 3 & $66.1 \%$ & 16 & $70.6 \%$ & 19 & $4.5 \%$ \\
\hline $\begin{array}{l}\text { Powell }+ \\
\text { O'Connor }\end{array}$ & $85.3 \%$ & 4 & $63.9 \%$ & 24 & $61.9 \%$ & 35 & $-2.0 \%$ \\
\hline $\begin{array}{l}\text { Scalia } \\
\text { Thomas }\end{array}$ & $84.9 \%$ & 5 & $70.2 \%$ & 8 & $83.2 \%$ & 4 & $13.0 \%$ \\
\hline $\begin{array}{l}\text { Burger } \\
\text { Powell } \\
\end{array}$ & $84.9 \%$ & 5 & $58.1 \%$ & 42 & $58.9 \%$ & 44 & $0.8 \%$ \\
\hline $\begin{array}{l}\text { Burger } \\
\text { White }\end{array}$ & $84.0 \%$ & 7 & $56.7 \%$ & 47 & $73.7 \%$ & 10 & $17.0 \%$ \\
\hline $\begin{array}{l}\text { Rehnquist }+ \\
\text { Powell }\end{array}$ & $83.1 \%$ & 8 & $63.1 \%$ & 26 & $66.3 \%$ & 30 & $3.2 \%$ \\
\hline $\begin{array}{l}\text { Rehnquist }+ \\
\text { O'Connor }\end{array}$ & $82.4 \%$ & 9 & $72.0 \%$ & 4 & $75.8 \%$ & 9 & $3.8 \%$ \\
\hline $\begin{array}{l}\text { Rehnquist }+ \\
\text { Kennedy }\end{array}$ & $80.8 \%$ & 10 & $67.9 \%$ & 13 & $72.9 \%$ & 12 & $5.0 \%$ \\
\hline $\begin{array}{l}\text { Rehnquist + } \\
\text { White }\end{array}$ & $80.7 \%$ & 11 & $69.7 \%$ & 9 & $72.6 \%$ & 16 & $2.9 \%$ \\
\hline $\begin{array}{l}\text { Rehnquist }+ \\
\text { Scalia }\end{array}$ & $78.4 \%$ & 12 & $66.3 \%$ & 15 & $76.6 \%$ & 8 & $10.3 \%$ \\
\hline $\begin{array}{l}\text { White } \\
\text { Powell }\end{array}$ & $78.0 \%$ & 13 & $64.1 \%$ & 23 & $70.6 \%$ & 20 & $6.5 \%$ \\
\hline
\end{tabular}

${ }^{* *}$ Merits agreement rates are from the Harvard Law Review's statistical recaps of the Supreme Court Terms, which can be found in the first issue of each of Volumes 98-108. 


\begin{tabular}{|c|c|c|c|c|c|c|c|}
\hline Pairing & $\begin{array}{c}\text { Merits } \\
\text { Avg. }\end{array}$ & $\begin{array}{c}\text { Ordinal } \\
\text { Rank }\end{array}$ & $\begin{array}{c}\text { Cert } \\
\text { Avg. } \\
\text { (All } \\
\text { Cases) }\end{array}$ & $\begin{array}{c}\text { Ordinal } \\
\text { Rank }\end{array}$ & $\begin{array}{c}\text { High- } \\
\text { Profile } \\
\text { Avg. }\end{array}$ & $\begin{array}{c}\text { Ordinal } \\
\text { Rank }\end{array}$ & $\begin{array}{c}\text { Difference } \\
\text { Between } \\
\text { H-P Avg. } \\
\text { and All } \\
\text { Cert Avg. }\end{array}$ \\
\hline $\begin{array}{l}\text { O'Connor + } \\
\text { Kennedy }\end{array}$ & $77.8 \%$ & 14 & $64.8 \%$ & 21 & $72.0 \%$ & 17 & $7.2 \%$ \\
\hline $\begin{array}{l}\text { Scalia }+ \\
\text { Kennedy }\end{array}$ & $77.8 \%$ & 14 & $72.1 \%$ & 3 & $73.1 \%$ & 11 & $1.0 \%$ \\
\hline $\begin{array}{l}\text { Brennan } \\
\text { Blackmun }\end{array}+$ & $77.2 \%$ & 16 & $54.7 \%$ & 50 & $67.0 \%$ & 27 & $12.3 \%$ \\
\hline $\begin{array}{l}\text { Souter } \\
\text { Ginsburg }\end{array}$ & $77.0 \%$ & 17 & $79.3 \%$ & 2 & $81.8 \%$ & 5 & $2.5 \%$ \\
\hline $\begin{array}{l}\text { Marshall }+ \\
\text { Blackmun }\end{array}$ & $76.8 \%$ & 18 & $56.4 \%$ & 48 & $78.8 \%$ & 6 & $10.5 \%$ \\
\hline $\begin{array}{l}\text { Rehnquist + } \\
\text { Thomas }\end{array}$ & $76.8 \%$ & 18 & $68.3 \%$ & 12 & $62.7 \%$ & 34 & $6.3 \%$ \\
\hline $\begin{array}{l}\text { Stevens } \\
\text { Ginsburg }\end{array}$ & $75.9 \%$ & 20 & $69.6 \%$ & 10 & $72.7 \%$ & 13 & $3.1 \%$ \\
\hline $\begin{array}{l}\text { White } \\
\text { Kennedy }\end{array}$ & $75.8 \%$ & 21 & $58.4 \%$ & 41 & $59.2 \%$ & 42 & $0.8 \%$ \\
\hline $\begin{array}{l}\text { White } \\
\text { O'Connor }\end{array}$ & $75.4 \%$ & 22 & $71.6 \%$ & 6 & $70.2 \%$ & 22 & $-1.4 \%$ \\
\hline $\begin{array}{l}\text { Kennedy } \quad+ \\
\text { Souter }\end{array}$ & $75.1 \%$ & 23 & $65.8 \%$ & 18 & $70.6 \%$ & 21 & $4.8 \%$ \\
\hline White + Souter & $73.5 \%$ & 24 & $59.0 \%$ & 39 & $69.0 \%$ & 24 & $10.0 \%$ \\
\hline $\begin{array}{l}\text { Powell } \\
\text { Scalia } \\
\end{array}$ & $73.5 \%$ & 24 & $50.0 \%$ & 57 & $54.5 \%$ & 50 & $4.5 \%$ \\
\hline $\begin{array}{l}\text { O'Connor + } \\
\text { Souter }\end{array}$ & $72.9 \%$ & 26 & $63.5 \%$ & 25 & $59.9 \%$ & 39 & $-3.6 \%$ \\
\hline $\begin{array}{l}\text { Kennedy } \\
\text { Thomas }\end{array}$ & $71.9 \%$ & 27 & $68.5 \%$ & 11 & $77.8 \%$ & 7 & $9.3 \%$ \\
\hline $\begin{array}{l}\text { Powell }+ \\
\text { Blackmun }\end{array}$ & $71.3 \%$ & 28 & $60.6 \%$ & 34 & $47.4 \%$ & 61 & $-13.2 \%$ \\
\hline $\begin{array}{l}\text { O'Connor }+ \\
\text { Scalia }\end{array}$ & $71.2 \%$ & 29 & $61.2 \%$ & 32 & $61.8 \%$ & 36 & $0.6 \%$ \\
\hline $\begin{array}{l}\text { Rehnquist }+ \\
\text { Souter }\end{array}$ & $71.1 \%$ & 30 & $62.6 \%$ & 28 & $61.2 \%$ & 38 & $-1.4 \%$ \\
\hline
\end{tabular}




\begin{tabular}{|c|c|c|c|c|c|c|c|}
\hline Pairing & $\begin{array}{c}\text { Merits } \\
\text { Avg. }\end{array}$ & $\begin{array}{c}\text { Ordinal } \\
\text { Rank }\end{array}$ & $\begin{array}{c}\text { Cert } \\
\text { Avg. } \\
\text { (All } \\
\text { Cases) }\end{array}$ & $\begin{array}{c}\text { Ordinal } \\
\text { Rank }\end{array}$ & $\begin{array}{c}\text { High- } \\
\text { Profile } \\
\text { Avg. }\end{array}$ & $\begin{array}{c}\text { Ordinal } \\
\text { Rank }\end{array}$ & $\begin{array}{c}\text { Difference } \\
\text { Between } \\
\text { H-P Avg. } \\
\text { and All } \\
\text { Cert Avg. }\end{array}$ \\
\hline $\begin{array}{l}\text { Blackmun } \\
\text { Stevens }\end{array}$ & $70.3 \%$ & 31 & $59.7 \%$ & 37 & $66.6 \%$ & 28 & $6.9 \%$ \\
\hline $\begin{array}{l}\text { Brennan }+ \\
\text { Stevens }\end{array}$ & $70.3 \%$ & 31 & $60.3 \%$ & 36 & $70.1 \%$ & 23 & $9.8 \%$ \\
\hline White + Scalia & $69.9 \%$ & 33 & $58.0 \%$ & 43 & $59.6 \%$ & 40 & $1.6 \%$ \\
\hline $\begin{array}{l}\text { O'Connor }+ \\
\text { Ginsburg }\end{array}$ & $69.8 \%$ & 34 & $65.2 \%$ & 19 & $72.7 \%$ & 14 & $7.5 \%$ \\
\hline $\begin{array}{l}\text { Marshall }+ \\
\text { Stevens }\end{array}$ & $69.8 \%$ & 34 & $61.3 \%$ & 31 & $71.1 \%$ & 18 & $9.8 \%$ \\
\hline $\begin{array}{l}\text { Blackmun }+ \\
\text { Ginsburg }\end{array}$ & $68.2 \%$ & 36 & $71.7 \%$ & 5 & $90.9 \%$ & 1 & $19.2 \%$ \\
\hline $\begin{array}{l}\text { White } \\
\text { Thomas }\end{array}$ & $67.8 \%$ & 37 & $70.3 \%$ & 7 & $51.5 \%$ & 55 & $-18.8 \%$ \\
\hline $\begin{array}{l}\text { Burger }+ \\
\text { Blackmun }\end{array}$ & $66.8 \%$ & 38 & $50.0 \%$ & 58 & $42.7 \%$ & 69 & $-7.3 \%$ \\
\hline $\begin{array}{l}\text { Rehnquist }+ \\
\text { Ginsburg } \\
\end{array}$ & $66.7 \%$ & 39 & $53.3 \%$ & 52 & $63.6 \%$ & 32 & $10.3 \%$ \\
\hline Scalia + Souter & $65.8 \%$ & 40 & $64.1 \%$ & 22 & $65.4 \%$ & 31 & $1.3 \%$ \\
\hline $\begin{array}{l}\text { O'Connor }+ \\
\text { Thomas }\end{array}$ & $65.5 \%$ & 41 & $61.8 \%$ & 30 & $58.5 \%$ & 45 & $-3.3 \%$ \\
\hline $\begin{array}{l}\text { Blackmun }+ \\
\text { Souter }\end{array}$ & $64.9 \%$ & 42 & $62.9 \%$ & 27 & $66.4 \%$ & 29 & $3.5 \%$ \\
\hline $\begin{array}{l}\text { White } \quad+ \\
\text { Blackmun }\end{array}$ & $64.5 \%$ & 43 & $66.0 \%$ & 17 & $59.0 \%$ & 43 & $-7.0 \%$ \\
\hline $\begin{array}{l}\text { Kennedy } \quad+ \\
\text { Ginsburg }\end{array}$ & $64.4 \%$ & 44 & $58.7 \%$ & 40 & $54.5 \%$ & 51 & $-4.2 \%$ \\
\hline $\begin{array}{l}\text { Stevens } \\
\text { Souter }\end{array}$ & $62.2 \%$ & 45 & $60.5 \%$ & 35 & $61.3 \%$ & 37 & $0.8 \%$ \\
\hline $\begin{array}{l}\text { Scalia } \\
\text { Ginsburg }\end{array}$ & $62.1 \%$ & 46 & $65.2 \%$ & 20 & $72.7 \%$ & 15 & $7.5 \%$ \\
\hline $\begin{array}{l}\text { Blackmun }+ \\
\text { O'Connor }\end{array}$ & $60.5 \%$ & 47 & $61.9 \%$ & 29 & $68.3 \%$ & 25 & $6.4 \%$ \\
\hline $\begin{array}{l}\text { White } \quad+ \\
\text { Stevens }\end{array}$ & $60.4 \%$ & 48 & $50.1 \%$ & 56 & $48.7 \%$ & 59 & $-1.4 \%$ \\
\hline
\end{tabular}




\begin{tabular}{|c|c|c|c|c|c|c|c|}
\hline Pairing & $\begin{array}{l}\text { Merits } \\
\text { Avg. }\end{array}$ & $\begin{array}{c}\text { Ordinal } \\
\text { Rank }\end{array}$ & $\begin{array}{c}\text { Cert } \\
\text { Avg. } \\
\text { (All } \\
\text { Cases) }\end{array}$ & $\begin{array}{c}\text { Ordinal } \\
\text { Rank }\end{array}$ & $\begin{array}{c}\text { High- } \\
\text { Profile } \\
\text { Avg. }\end{array}$ & $\begin{array}{c}\text { Ordinal } \\
\text { Rank }\end{array}$ & $\begin{array}{c}\text { Difference } \\
\text { Between } \\
\text { H-P Avg. } \\
\text { and All } \\
\text { Cert Avg. }\end{array}$ \\
\hline $\begin{array}{l}\text { Souter } \\
\text { Thomas }\end{array}$ & $60.1 \%$ & 49 & $61.0 \%$ & 33 & $67.5 \%$ & 26 & $6.5 \%$ \\
\hline $\begin{array}{l}\text { Powell }+ \\
\text { Brennan }\end{array}$ & $59.1 \%$ & 50 & $49.8 \%$ & 59 & $51.0 \%$ & 56 & $1.2 \%$ \\
\hline $\begin{array}{l}\text { Powell } \\
\text { Stevens }\end{array}$ & $57.9 \%$ & 51 & $49.5 \%$ & 60 & $56.9 \%$ & 46 & $7.4 \%$ \\
\hline $\begin{array}{l}\text { Stevens } \\
\text { O'Connor }\end{array}$ & $57.8 \%$ & 52 & $50.3 \%$ & 55 & $54.7 \%$ & 49 & $4.4 \%$ \\
\hline $\begin{array}{l}\text { Blackmun + } \\
\text { Kennedy }\end{array}$ & $57.7 \%$ & 53 & $56.7 \%$ & 46 & $59.5 \%$ & 41 & $2.8 \%$ \\
\hline $\begin{array}{l}\text { Powell } \\
\text { Marshall }\end{array}$ & $57.0 \%$ & 54 & $47.3 \%$ & 64 & $43.8 \%$ & 66 & $-3.5 \%$ \\
\hline $\begin{array}{l}\text { Stevens } \\
\text { Kennedy }\end{array}$ & $56.5 \%$ & 55 & $51.1 \%$ & 53 & $55.5 \%$ & 48 & $4.4 \%$ \\
\hline $\begin{array}{l}\text { Brennan } \\
\text { White }\end{array}$ & $55.7 \%$ & 56 & $48.9 \%$ & 62 & $40.2 \%$ & 71 & $-6.3 \%$ \\
\hline $\begin{array}{l}\text { Rehnquist } \\
\text { Blackmun }\end{array}$ & $55.0 \%$ & 57 & $59.4 \%$ & 38 & $44.2 \%$ & 65 & $-4.7 \%$ \\
\hline $\begin{array}{l}\text { Burger } \\
\text { Stevens }\end{array}$ & $54.8 \%$ & 58 & $46.1 \%$ & 67 & $54.4 \%$ & 52 & $-5.0 \%$ \\
\hline $\begin{array}{l}\text { Marshall } \\
\text { Souter }\end{array}$ & $54.6 \%$ & 59 & $48.8 \%$ & 63 & $37.8 \%$ & 73 & $-8.3 \%$ \\
\hline $\begin{array}{l}\text { Marshall } \\
\text { White }\end{array}$ & $54.0 \%$ & 60 & $51.0 \%$ & 54 & $56.3 \%$ & 47 & $7.5 \%$ \\
\hline $\begin{array}{l}\text { Burger } \\
\text { Brennan } \\
\end{array}$ & $53.9 \%$ & 61 & $36.3 \%$ & 76 & $43.3 \%$ & 67 & $-7.7 \%$ \\
\hline $\begin{array}{l}\text { Brennan } \\
\text { Kennedy }\end{array}$ & $53.7 \%$ & 62 & $41.1 \%$ & 73 & $29.7 \%$ & 76 & $-6.6 \%$ \\
\hline $\begin{array}{l}\text { Brennan } \\
\text { O'Connor }\end{array}$ & $53.2 \%$ & 63 & $41.9 \%$ & 72 & $53.8 \%$ & 53 & $12.7 \%$ \\
\hline $\begin{array}{l}\text { Rehnquist }+ \\
\text { Stevens }\end{array}$ & $53.0 \%$ & 64 & $41.0 \%$ & 74 & $45.0 \%$ & 64 & $3.1 \%$ \\
\hline $\begin{array}{l}\text { Thomas } \\
\text { Ginsburg }\end{array}$ & $52.9 \%$ & 65 & $57.6 \%$ & 44 & $43.2 \%$ & 68 & $2.2 \%$ \\
\hline
\end{tabular}




\begin{tabular}{|l|l|l|l|l|l|l|l|}
\hline \multicolumn{1}{|c|}{ Pairing } & $\begin{array}{c}\text { Merits } \\
\text { Avg. }\end{array}$ & $\begin{array}{c}\text { Ordinal } \\
\text { Rank }\end{array}$ & $\begin{array}{c}\text { Cert } \\
\text { Avg. } \\
\text { (All } \\
\text { Cases) }\end{array}$ & $\begin{array}{c}\text { Ordinal } \\
\text { Rank }\end{array}$ & $\begin{array}{c}\text { High- } \\
\text { Profile } \\
\text { Avg. }\end{array}$ & $\begin{array}{c}\text { Ordinal } \\
\text { Rank } \\
\text { Between } \\
\text { H-P Avg. } \\
\text { and All } \\
\text { Cert Avg. }\end{array}$ \\
\hline $\begin{array}{l}\text { Marshall } \\
\text { Kennedy }\end{array}$ & $51.2 \%$ & 66 & $47.2 \%$ & 65 & $63.6 \%$ & 33 & $6.0 \%$ \\
\hline $\begin{array}{l}\text { Marshall } \\
\text { O'Connor }\end{array}$ & $50.6 \%$ & 67 & $44.6 \%$ & 69 & $50.1 \%$ & 57 & $2.9 \%$ \\
\hline $\begin{array}{l}\text { Burger } \\
\text { Marshall }\end{array}$ & $49.4 \%$ & 68 & $42.5 \%$ & 70 & $45.6 \%$ & 63 & $1.0 \%$ \\
\hline $\begin{array}{l}\text { Blackmun } \\
\text { Scalia }\end{array}$ & $49.2 \%$ & 69 & $54.1 \%$ & 51 & $33.6 \%$ & 75 & $-8.9 \%$ \\
\hline $\begin{array}{l}\text { Stevens } \\
\text { Scalia }\end{array}$ & $48.9 \%$ & 70 & $49.1 \%$ & 61 & $48.6 \%$ & 60 & $-5.5 \%$ \\
\hline $\begin{array}{l}\text { Rehnquist } \\
\text { Brennan }+\end{array}$ & $48.0 \%$ & 71 & $40.6 \%$ & 75 & $47.4 \%$ & 62 & $-1.7 \%$ \\
\hline $\begin{array}{l}\text { Brennan } \\
\text { Scalia }\end{array}$ & $47.5 \%$ & 72 & $45.6 \%$ & 68 & $36.0 \%$ & 74 & $-4.6 \%$ \\
\hline $\begin{array}{l}\text { Rehnquist } \\
\text { Marshall }\end{array}$ & $45.6 \%$ & 73 & $42.3 \%$ & 71 & $40.9 \%$ & 70 & $-4.7 \%$ \\
\hline $\begin{array}{l}\text { Marshall } \\
\text { Scalia }+\end{array}$ & $45.0 \%$ & 74 & $46.5 \%$ & 66 & $38.2 \%$ & 72 & $-4.1 \%$ \\
\hline $\begin{array}{l}\text { Blackmun } \\
\text { Thomas }+\end{array}$ & $44.4 \%$ & 75 & $57.5 \%$ & 45 & $49.9 \%$ & 58 & $-7.6 \%$ \\
\hline $\begin{array}{l}\text { Stevens } \\
\text { Thomas }\end{array}$ & $42.3 \%$ & 76 & $56.2 \%$ & 49 & $53.1 \%$ & 54 & $-3.1 \%$ \\
\hline
\end{tabular}

